\title{
A new species of Typhlatya (Crustacea: Decapoda: Atyidae) from anchialine caves on the French Mediterranean coast
}

\author{
DAMIÀ JAUME ${ }^{1 *}$ and FRANCK BRÉHIER ${ }^{2}$ \\ ${ }^{1}$ IMEDEA (CSIC-UIB), Instituto Mediterráneo de Estudios Avanzados, C/. Miquel Marquès 21, E-07190 \\ Esporles (Mallorca), Spain \\ ${ }^{2}$ Alas, F-09800 Balaguères, France
}

Received June 2004; accepted for publication March 2005

\begin{abstract}
A new species of the thermophylic Tethyan relict prawn Typhlatya is described from two anchialine caves near Perpignan (southern France). The new species is closely related to a congener known only from a freshwater cave at Castellón (eastern Spain), about $400 \mathrm{~km}$ to the south-west, differing apparently only in the size and shape of the rostrum and the armature of the dactylus of the fifth pereiopod. Based on palaeogeographical evidence and assuming a sistergroup relationship between both species, we suggest that their common ancestor could not be older than early Pliocene in age, and that it was already a stygobiont taxon adapted to live in shallow-water marine crevicular habitats. This ancestor would have vanished from the western Mediterranean after the cooling associated with the onset of northern Hemisphere glaciation, about $3 \mathrm{Mya}$, as documented for other Mediterranean marine taxa. Indeed, the genus is completely stygobiont and does not occur in fluvial environments. The Pyrenees represent a watershed boundary that eliminates the possibility of the derivation of one species from the other by active dispersal after establishment in continental waters. (c) 2005 The Linnean Society of London, Zoological Journal of the Linnean Society, 2005, 144, 387-414.
\end{abstract}

ADDITIONAL KEYWORDS: biogeography - France - stygofauna - systematics - Tethyan relicts - vicariance.

\section{INTRODUCTION}

In 1973 the French biologist J. Y. Bertrand collected a single specimen of a blind atyid prawn in the cave of Font Estramar, a small cave opening just above a spring of the same name in Massif des Corbières (Pyrénées-orientales, France). He identified it as Troglocaris sp., presumably with reference to the presence of Troglocaris inermis Fage, 1937 in the nearby karsts of Hérault, where the stygofauna is similar to that of Corbières (Bertrand, 1974). Hitherto Troglocaris Dormitzer, 1853, together with the monotypic Spelaeocaris pretneri Matjasic, 1956 from caves in Herzegovina, were the only stygobiont atyid genera known from the peri-Mediterranean region. Troglocaris, with nine recognized species (see d'Udekem d'Acoz, 1999) is limited to coastal regions on the northern rim of the Mediterranean, from the Gulf of Lyon in

\footnotetext{
*Corresponding author. E-mail: d.jaume@uib.es
}

France to the Black Sea coast of the Republic of Georgia.

Two other epigean, occulate atyid genera occur in the area and are endemic to it: the first is Dugastella Bouvier, 1912, with two species, one restricted to Morocco, the other to coastal marshes of the Spanish Levant; the second is the circum-Mediterranean Atyaephyra desmaresti (Millet, 1931), with three recognized subspecies (d'Udekem d'Acoz, 1999). A third genus, Caridina H. Milne Edwards, 1837, broadly spread along the Indo-Pacific, Asia and Africa south to the Sahara, has been reported from close to the Mediterranean Levantine Region (Mediterranean Nile; Suez Canal; Syria; see d'Udekem d'Acoz, 1999), but not from the Mediterranean proper.

The Mediterranean was apparently devoid of stygobiont atyids belonging to thalassoid genera displaying extreme disjunct distributions, such as those known in oceanic island groups of both the Atlantic and IndoPacific. That was the picture until the remarkable discovery of a new species of Typhlatya Creaser, 1936 in 
Spain by Sanz \& Platvoet (1995), who also transferred the monotypic Spelaeocaris to Typhlatya. This represented the first undeniable relict Tethyan distribution known among European decapods. Later, based on the emended diagnoses of atyid genera presented by Holthuis (1993), d'Udekem d'Acoz (1999) added another Eurasiatic Typhlatya to the list, by transferring the Georgian Troglocaris schmidti jusbaschjani Birstein, 1948 to Typhlatya (as T. jusbaschjani).

In November 2001, and again in 2002 and 2003, during the Pascalis project (see http://www.pascalisproject.com/), Font Estramar was repeatedly surveyed by one of us (FB) in order to catalogue its stygofauna. The prawn recorded there by J. Y. Bertrand was collected in large numbers. Following detailed comparison with material from the type locality, it was recognized as a related, new species, distinguishable by the ornamentation of the dactylus of the fifth pereiopod and by the shape of the rostrum, from Typhlatya miravetensis Sanz \& Platvoet, 1995, which is endemic to a single limestone freshwater cave in the Spanish province of Castellón. In 2003 we found the prawn in a second cave, the Grotte des Fées de Leucate, situated some $7 \mathrm{~km}$ to the north-east of Font Estramar.

This paper provides a detailed description of the new species, with a special emphasis on the determination of the segmental homologies of all limbs, in order to provide a better basis for comparison with other species of the genus and with related genera. The paper also constitutes the first record of anchialine caves in metropolitan France.

\section{MATERIAL AND METHODS}

Most of the prawns were caught in traps baited with strips of raw beef and set in the submerged passages of the caves using specialized cave diving techniques. Other specimens were captured by hand, the animals often entering the open water column and being illuminated by torchlight. Salinity and temperature profiles of the water column in Grotte des Fées de Leucate were produced with a Seabird SBE19 CTD oceanographic profiler programmed to take readings every $0.5 \mathrm{~s}$. The descent of the profiler was controlled to a rate of $c .10 \mathrm{~cm} \mathrm{~s}^{-1}$; the device was held out in front by the diver to avoid disturbing the water column. Specimens were fixed in the field in ethanol and treated in the laboratory with hot lactic acid to remove internal tissue. Black Chlorazol B cuticular staining was used following the procedure described in Wagner (1994). Drawings were prepared using a camera lucida on an Olympus BH-2 microscope equipped with Nomarski differential interference contrast. Body measurements were derived from the sum of the maximum dorsal dimensions of the carapace (rostrum included), free somites, and telson. Material is deposited in the Crustacea collection of the Departement des Milieux et Peuplements Marins, Muséum national d'Histoire naturelle, Paris (MNHN).

\section{THE CAVES}

Font Estramar is an important artesian spring that opens in the limestone of the Massif des Corbières (Early Cretaceous; see Aunay et al., 2002) about $150 \mathrm{~m}$ inland from the inner shore of the Mediterranean coastal lagoon of Salses-Leucate (Salses-lechâteau; Pyrénées-orientales, south-west France; Fig. 1). The lagoon, with a surface area of $54 \mathrm{~km}^{2}$ and a maximum depth of $3.70 \mathrm{~m}$, is separated from the sea by a sand bar. Water salinity is slightly lower (22$35 \%$, depending on the local conditions) than in the sea nearby $(37.1 \%$ ).

Underwater exploration of the spring started in 1949 and the extent of surveyed passages has increased progressively since then, in line with the improvements in cave diving techniques. Considering the complexity of the cave, the Association de Recherches de Font Estramar (ARFE) was created in 1991 to coordinate its exploration, leading to the survey of more than $2800 \mathrm{~m}$ of underwater passages. The current explored limit in the cave was reached in 1996 by ARFE's cave diver Cyrille Brandt, who reached a depth of $-164 \mathrm{~m}$ at $850 \mathrm{~m}$ from the entrance (Brandt, 1997). It has been estimated that the karstification at the spring area extends $350 \mathrm{~m}$, with an even greater potential as the thickness of the limestone is around $1000 \mathrm{~m}$ (Ladouche et al., 2004).

Font Estramar and Font Dame are the main water sources within the large and complex karstic system of Corbières d'Opoul (Salvayre, 1978, 2002). The large associated aquifer derives around $30 \%$ of its water from rainfall, the remainder coming from sinks in the Agly and Verdouble riverbeds (Ladouche et al., 2004). The outflow of Font Estramar has, over the last 30 years, averaged $2.1 \mathrm{~m}^{3} \mathrm{~s}^{-1}$, fluctuating from $0.8 \mathrm{~m}^{3} \mathrm{~s}^{-1}$ to more than $30 \mathrm{~m}^{3} \mathrm{~s}^{-1}$ during floods. The water is characterized by a slightly elevated temperature and oligohaline state (salinity range $0.2-2.2 \%$, depending on the spring's outflow volume; Kiener \& Petit, 1968; Ladouche et al., 2004). Recent studies (Ladouche et al., 2004) indicate that the salinity derives from the water of the coastal lagoon. The deep intrusion and circulation of this water would explain its elevated temperature, ranging from 15.6 to $18.6^{\circ} \mathrm{C}$ at the spring's outlet (Cyrille Brandt, pers. comm.).

Typhlatya arfeae sp. nov. has been collected in Font Estramar from the entrance to the so-called Puits du Silence (see map in Brandt, 1997), although it has also been observed by divers further within the cave. The species seems to be more abundant in the Galerie 

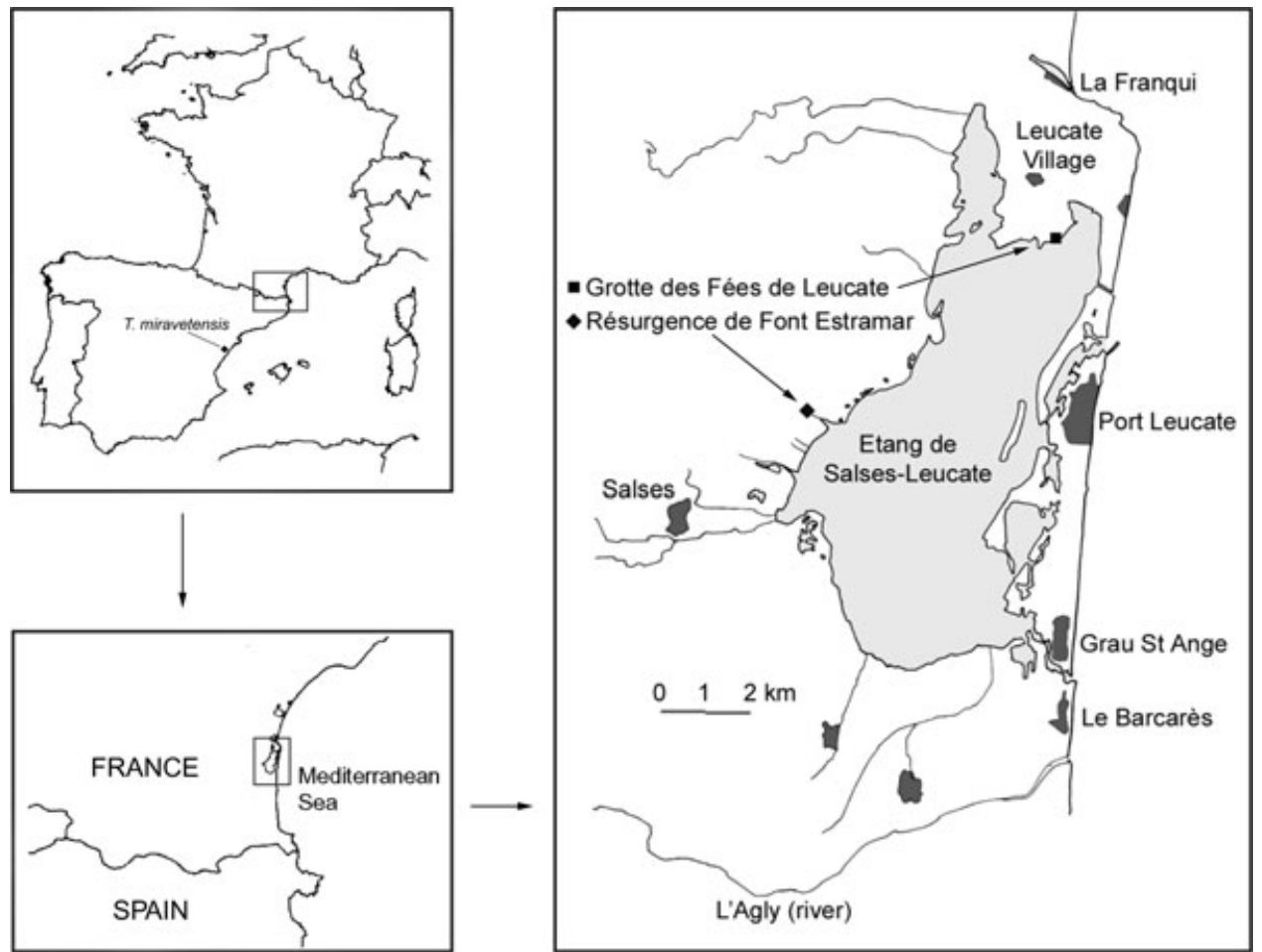

Figure 1. Location of the two caves harbouring Typhlatya arfeae sp. nov. in south-eastern France plus the single locality of the closely related T. miravetensis Sanz \& Platvoet, 1995 in eastern Spain.

Chaude, where the temperature and salinity are higher, and the conditions (turbidity, flow) more stable. It has been observed together with a cirolanid isopod (Faucheria sp.) and the amphipod Niphargus delamarei Ruffo, 1954 (Bertrand, 1973, 1974).

Grotte des Fées de Leucate (Fig. 1), excavated in Early Cretaceous limestone (see Aunay et al., 2002), opens only $40 \mathrm{~m}$ from the northern shore of the coastal lagoon of Salses-Leucate. It has five entrances interconnected by underwater passages. The main entrance leads to a submerged room followed by a gallery that reaches a depth of $-34 \mathrm{~m}$ at its furthest point. The total length of the cave exceeds $140 \mathrm{~m}$. The water is known to be brackish and recent analyses have demonstrated that the cave is currently disconnected from any karstic system (Ladouche et al., 2000).

Typhlatya arfeae sp. nov. has been observed in Grotte des Fées de Leucate throughout the entire water column, frequently swimming in open water. The accompanying fauna consisted of the stygobiotic amphipods Pseudoniphargus sp., Niphargus delamarei, and Niphargus angelieri Ruffo, 1954, the copepods Diacyclops bicuspidatus odessanus (Schmankevitch, 1875) and Calanipeda aquaedulcis Kritschagin, 1873, and the eel Anguilla anguilla (L.). Anguilla, Calanipeda, and Diacyclops are common in the Salses lagoon, and their presence in the cave suggests the existence of a connection to the lagoon that is inaccessible to divers.

\section{ON THE ANCHIALINE CONDITION OF THE CAVES}

During our first visit to Grotte des Fées de Leucate (17 April 2003), we noticed that a fresh-to-oligohaline water lens of $2 \mathrm{~m}$ overlaid a brackish water layer, with a sharp pycnocline between. No water currents were observed. Using an oceanographic probe, the CTD profile of the water column was produced on 7 December 2003 after several days of strong rainfall. The water level in the cave was then nearly $3 \mathrm{~m}$ higher than during our earlier visit. Aside from a surface layer $(3 \mathrm{~m})$ of mixed water, three additional pycnoclines were discernible at depths of 5-12, 18-20, and 32-34 m (Fig. 2). This superimposed series of pycnoclines could have been generated by sequential influxes of fresh water into the cave, which eventually mixed by diffusion with the saline layer immediately beneath. At the cave bottom, at a depth of $37 \mathrm{~m}$, salinity reached $22 \%$, which was the same as in the neighbouring lagoon at that time. Water temperature in the cave remained comparatively warm and stable, between 15.5 and $16.5^{\circ} \mathrm{C}$ along the entire column.

These hydrographic features, plus the presence of stygobiont organisms, suggest a typically anchialine 


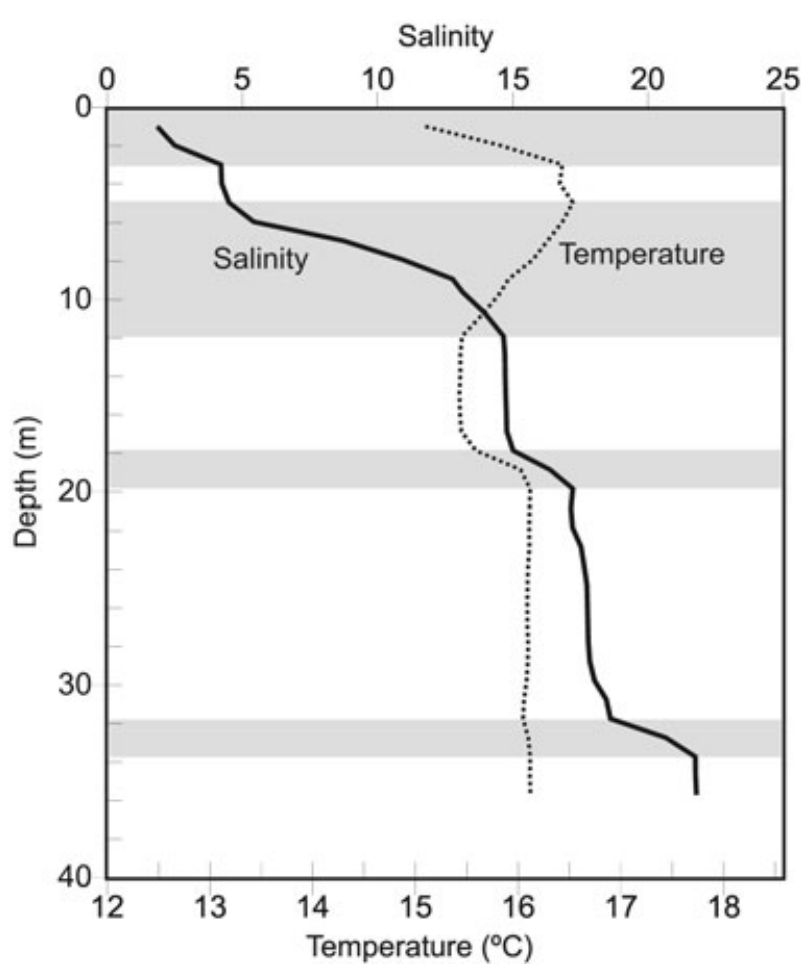

Figure 2. CTD profile of the water column at Grotte des Feés de Leucate, 7 December 2003. Layers in grey correspond to picnoclynes.

condition for the cave (Stock, Illife \& Williams, 1986; Sket, 1996). Grotte des Fées de Leucate is therefore the first anchialine cave recorded in metropolitan France. Similar anchialine habitats on the inner shore of coastal lagoons have been reported from the Dominican Republic (Jaume \& Wagner, 1998) and Mallorca (Encinas, 1983).

Font Estramar differs dramatically from Grotte des Fées de Leucate by its low salinity, its important outflow, and its lack of obvious stratification in the water column. Nevertheless, it can also be considered an anchialine habitat according to Sket (1996), who contended that any subterranean habitat where continental and marine waters and/or faunas may influence each other should be considered anchialine.

Typhlatya arfeae sp. nov. seems to be restricted to anchialine caves. Numerous ordinary freshwater caves belonging to the Corbières d'Opoul karstic system and located near the two caves inhabited by Typhlatya have been intensively surveyed for the prawn without any success (e.g. Gourg de l'Antre, Grotte du Presbytère, Résurgence du Mas d'En Caraman, Gouffre de Paziols, Barrenc de Villarzel, Grotte d'Allens, and Gouffre de la Tirounère). The distribution of the species seems also to be very localized, as it has not been recorded in two additional anchialine caves located c. $36 \mathrm{~km}$ (Aven Station, Fleury) and $27 \mathrm{~km}$ (Font Caude, Gruissan) to the NE of Grotte des Fées de Leucate.

\section{SYSTEMATICS}

ORDER DECAPODA LATREILle, 1802

Suborder PleOCYEMATA BURKENROAD, 1963

INFRAORDER CARIDEA DANA, 1852

SUPERFAMILY ATYOIDEA DE HAAN, 1849

FAMILY ATYIDAE DE HAAN, 1849

SUbFAMILY TYPHLATYINAE HOLTHUIS, 1986

GENUS TYPHLATYA CREASER, 1936

TYPHLATYA ARFEAE SP. NOV.

Material examined

Résurgence de Font Estramar (Salses-le-château; Pyrénées-orientales, France).

Holotype: specimen, sex unknown, body length $17.85 \mathrm{~mm}$ (MNHN no. 15773)

Paratypes: 11 specimens, sex unknown; body length (in $\mathrm{mm}$ ): 11.40, 16.85, 9.90, 11.45, 16.55, 12.25, 12.85, $15.20,15.60,14.00$ and $12.25 \mathrm{~mm}$ (MNHN no. 15774). Collected by Franck Bréhier, 17 April 2003.

Grotte des Fées de Leucate (Leucate; Aude, France). Two specimens, body length 17.30 and $16.30 \mathrm{~mm}$ (MNHN no. 15775). Collected by Franck Bréhier, 18 April 2003.

Comparative material examined

Typhlatya miravetensis Sanz \& Platvoet, 1995: three specimens, sex unknown, from type locality, deposited at the Department of Ecology and Microbiology, University of Valencia, Spain.

Typhlatya cf. monae Chace, 1954: Pozimán Cadena (Oviedo; Pedernales, Dominican Republic). Three specimens, sex unknown, deposited at IMEDEA. Collected by Damià Jaume, 8 November 1999.

Troglocaris inermis Fage, 1937: Gouffre des Cent Fonts (Causse de la Selle; Hérault, France). Three specimens, sex unknown, deposited at F. Bréhier's personal collection. Collected by Franck Bréhier, 31 May 2002.

\section{Diagnosis}

Eyes lacking pigment. Rostrum small, pointed, not extending beyond eyestalk and hardly beyond insertion of first peduncle segment of antennule. Sixth pleonite about 1.6 times longer than fifth pleonite. Antennulary stylocerite not reaching distal margin of first peduncle segment. Flagellar lobule of exopod of first maxilliped well developed and delimited from remainder of exopod. Armature along medial margin of dactylus of fifth pereiopod consisting of 19-28 
spines, each with row of tightly set denticles on one side, and row of long pinnules on other side and dorsally; spine series ending distally with two longer and stouter spines with ornamentation reduced to few marginal denticles along one side only. Exopod of fifth pereiopod well developed, attaining ischiomeral articulation of endopod. Telson 2.0-2.3 times longer than wide, with 12 terminal spines.

\section{Description}

Body up to $17.85 \mathrm{~mm}$ long, unpigmented (white when alive), with completely regressed eyes. Rostrum small and variably pointed (compare Figs $3 \mathrm{~A}, 4 \mathrm{~B}$ and 5), subtriangular in cross-section, triangular in dorsal aspect (Fig. 4A), lacking teeth and rostral ridge; sometimes with 1-2 tiny setae on ventral rim (see Fig. 3A). Rostrum hardly extending beyond insertion of first peduncle segment of antennule, in general shorter than eyestalks, but exceptionally reaching tip of eyestalk in some smaller specimens (Fig. 3A).

Carapace (Fig. 3A) rounded, 1.6 times longer than high, lacking spines or ridges; antennal and pterygostomial angles rounded, former hardly produced, not reaching tip of rostrum (Fig. 4A, B); posterolateral margins of carapace hardly extended posteriorly over first abdominal somite. Premarginal posterodorsal transverse suture scarcely developed; hepatic-branchiocardiac groove not observed.

Lateral body wall of fourth to eighth thoracomeres (corresponding to thoracomeres bearing first to fifth pereiopods) with one phyllobranchiate pleurobranch on each side, those on eighth thoracomere reduced (see Figs 3C, 13F, 15A). Sternite of eighth thoracomere with posterior margin weakly produced anteriorly into triangular process with subterminal tuft of setules (Fig. 4C); process not extending beyond insertion of fifth pereiopod.

Pleon (Fig. 3A) with intercalary dorsal sclerite between carapace and first pleonite; Pleurae of first five pleonites rounded. Sixth pleonite about 1.62 times longer than fifth, with posterolateral lobe on each side; lobe with tiny denticle as in Figure 3B. Posterior margin of sternite of sixth pleonite projecting mediodistally into narrow triangular process bearing subdistal setule on rounded tip (Fig. 18A); process probably homologous with the preanal plate of T. galapagensis, Stygiocaris stylifera Holthuis, 1960 and Antecaridina lauensis (Edmondson, 1935) (see Monod \& Cals, 1970: 97, figs 60-62), although in the new species, in T. miravetensis and in T. rogersi (and apparently also in T. mitchelli and T. campechae; see Hobbs \& Hobbs, 1976: 2, 6) this process is incorporated into the sternite and does not appear as a sep- arate sclerotized plate. Anus positioned on posterior margin of sixth pleonite, just below insertion of telson (Fig. 18A).

Eyestalks ellipsoid, about 1.6 times longer than wide, with reduced area of thin cuticle at distolateral corner (Fig. 4B). Conical frontal process present between insertion of eyestalks and insertion of antennules (Fig. 4A). Paired soft finger-like processes inserted laterodorsally, adjacent to insertion of antennules, and apparently functioning to lock eyestalks laterally (Fig. 4A); process homologous with two processes, beneath the eyes, placed above the dorsal part of the antennulary praecoxa of T. galapagensis (see Monod \& Cals, 1970: 73, fig. 23). At least in the new species this process is an integumental outgrowth of the body wall and does not form part of the antennule, as supposed by Monod \& Cals (1970).

Antennule with 3-segmented peduncle reaching transverse suture line (= diaeresis) on antennal scaphocerite (see Fig. 6A). Length ratio of peduncular segments 1-3 measured along medial margin approximately $0.41: 0.29: 0.30$. Dorsodistal margin of first and second peduncular segments each with setae inserted on biarticulate socle, remaining setation as in Figure 6A; first segment with stylocerite extending $82 \%$ length of segment; third segment with rounded process dorsodistally, apparently articulating with segment; process homologous with calcified plate mentioned in same position in T. galapagensis (see Monod \& Cals, 1970: 73, fig. 23). Outer flagellum (Fig. 6C) with aesthetascs on ventral surface of proximal annuli, distributed as figured; basal portion of aesthetascs with transverse constrictions giving a segmented appearance (Fig. 6D). Inner flagellum lacking aesthetascs (Fig. 6B).

Antenna with 5-segmented peduncle; first segment (coxa) with recurved, finger-like soft process on ventrolateral surface (Fig. 7C); process tentatively homologous with coxal orifice placed on a membranous outgrowth of T. galapagensis (see Monod \& Cals, 1970: 75, fig. 24). Second segment (basis) with two soft finger-like processes dorsolaterally (Fig. 7A, C), and acute tooth on ventromedial corner extending slightly beyond distal margin of third peduncular segment; outlet of antennary gland visible as soft conical process with terminal pore, located behind tooth. Third segment with single seta on distolateral corner. Fourth peduncular segment inserted on dorsomedial surface of preceding segment, with row of stout plumose setae, each on biarticulate socle, along distal and distolateral margins (Fig. 7B, C). Fifth segment elongate, about 2.2 times longer than wide, subrectangular, inserted dorsodistally on preceding segment, with cluster of smooth setae at distolateral corner. 


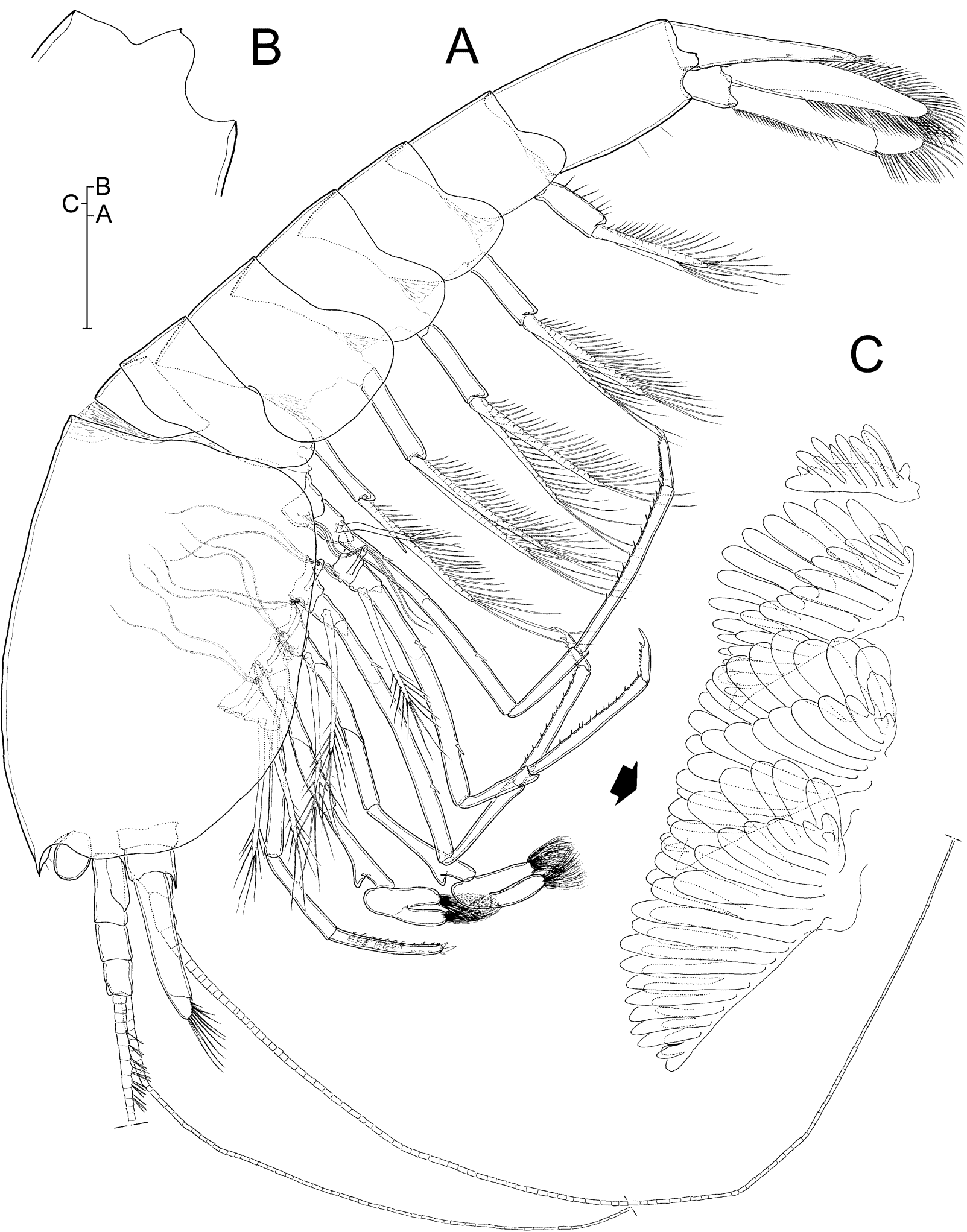

Figure 3. Typhlatya arfeae sp. nov., specimen $17.60 \mathrm{~mm}$, sex unknown. A, habitus of $12.25 \mathrm{~mm}$ paratype. B, detail of posterolateral lobe of sixth pleonite. $\mathrm{C}$, detail of left pleurobranchs on fifth to eighth thoracomeres (i.e. bearing pereiopods 2-5). Scale bar: $\mathrm{A}=1.0 \mathrm{~mm} ; \mathrm{B}, \mathrm{C}=0.5 \mathrm{~mm}$. 


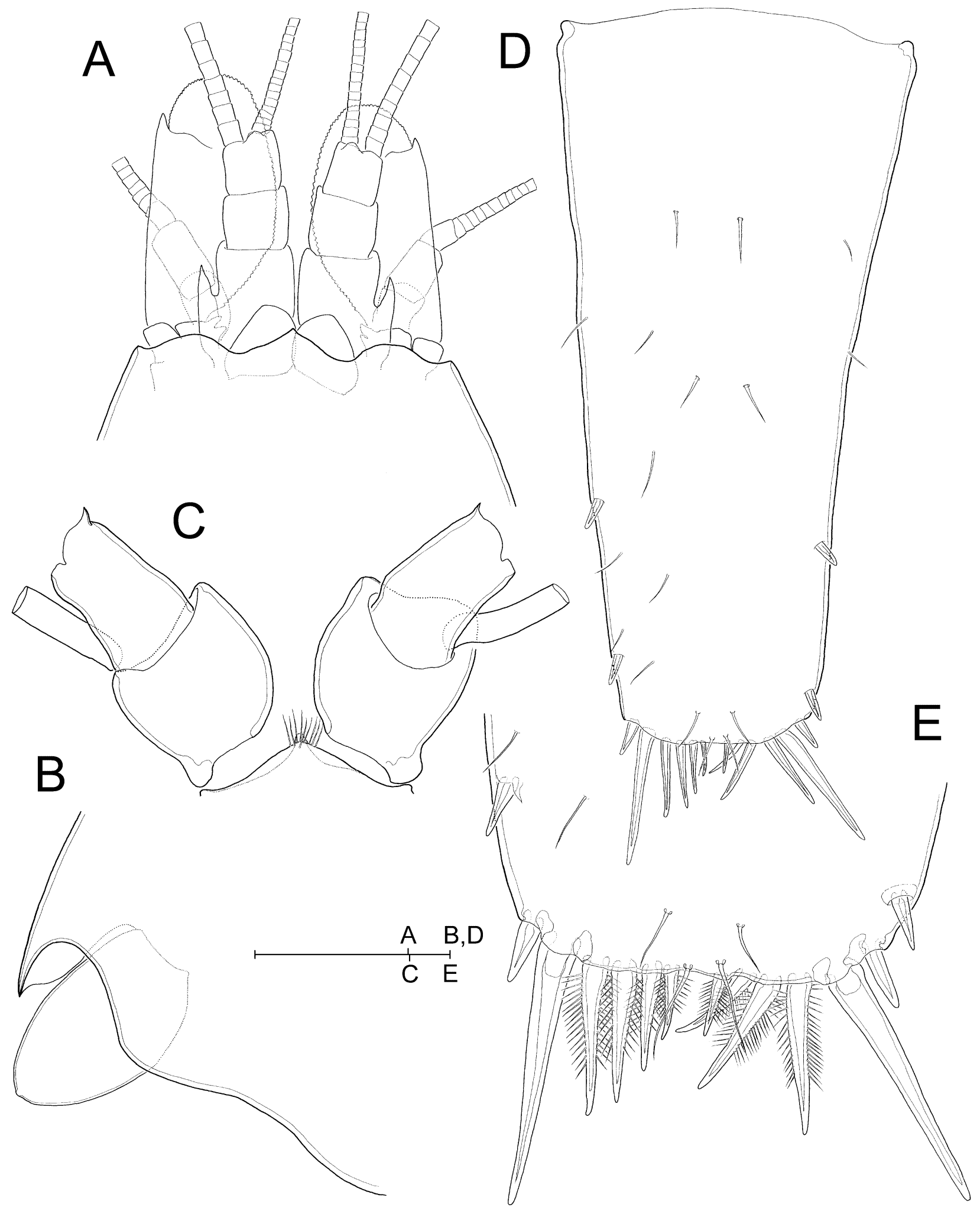

Figure 4. Typhlatya arfeae sp. nov., specimen $17.60 \mathrm{~mm}$, sex unknown. A, anterior part of carapace, dorsal. B, detail of rostrum and eyestalk, lateral. C, detail of posterior margin of sternite of eighth thoracomere, ventral. D, telson, dorsal. $\mathrm{E}$, detail of distal armature of telson, dorsal. Scale bar: $\mathrm{A}=1.0 \mathrm{~mm} ; \mathrm{B}-\mathrm{D}=0.5 \mathrm{~mm} ; \mathrm{E}=0.25 \mathrm{~mm}$. 

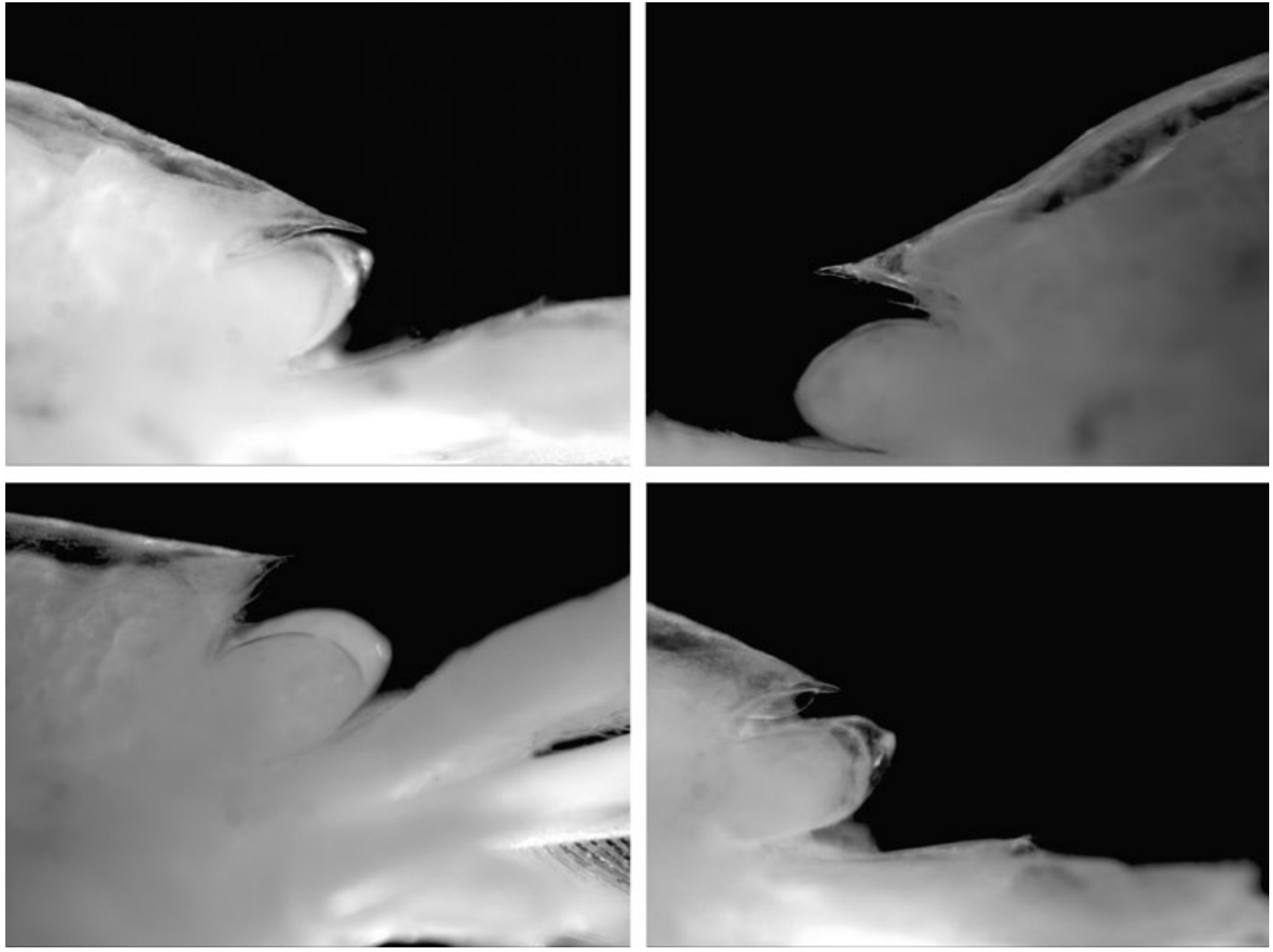

Figure 5. Typhlatya arfeae sp. nov., sex unknown. Variability in form of rostrum of different specimens (see also Figs 3A, 4B).

Scaphocerite inserted ventrolaterally on second peduncular segment, about 2.2 times longer than wide, with straight medial margin ending in pointed process; transverse integumental suture line (= diaeresis) extending from insertion of pointed process to about midway along scaphocerite. Outer margin of scaphocerite convex, distal margin evenly rounded; both margins fringed with plumose setae with transverse endocuticular interruptions giving a segmented appearance (Fig. 4A). Flagellum multiannulate, with proximal annuli incompletely separated (Fig. 4B).

Labrum (not figured) globular, constricted proximally, with setulose free posterodistal margin; two lateral and one frontal pointed process on constricted proximal part. Labium (Fig. 12G) deeply incised, V-shaped, each lobe (= paragnath) expanded distally, massive, ornamented with densely set setules along medial margin and carrying single smooth seta distolaterally on posterior surface.
Mandibles asymmetrical, lacking palp and lacinia mobilis, with sparsely set short plumose setae on surface of proximal part of coxal gnathobase (Fig. 8A). Left mandible (Fig. 8A) with incisor bearing three superimposed triangular teeth at anterodistal corner and blunt, truncate tooth at posterodistal corner. Setal row (= 'ventral row of lifting spines' of Fryer, 1977) consisting of four spinulose elements as in Figure 6B. Proximal portion of mandibular sinus with two superimposed marginal rows of slender plumose setae (= 'dorsal row of lifting spines' of Fryer, 1977), anteriormost row composed of shorter setae. Molar process large, with grinding surface strongly curved transversely and composed of parallel striated plates with tuberculate rim, each plate with short spinule distally (Fig. 8C); spinules progressively shorter, absent from plates on molar crown. Right mandible (Fig. 8D) with incisor narrower than on left counterpart, composed of six sharp triangular teeth (Fig. 8E). Setal row of five spinulose elements, more slender and less spinulose 


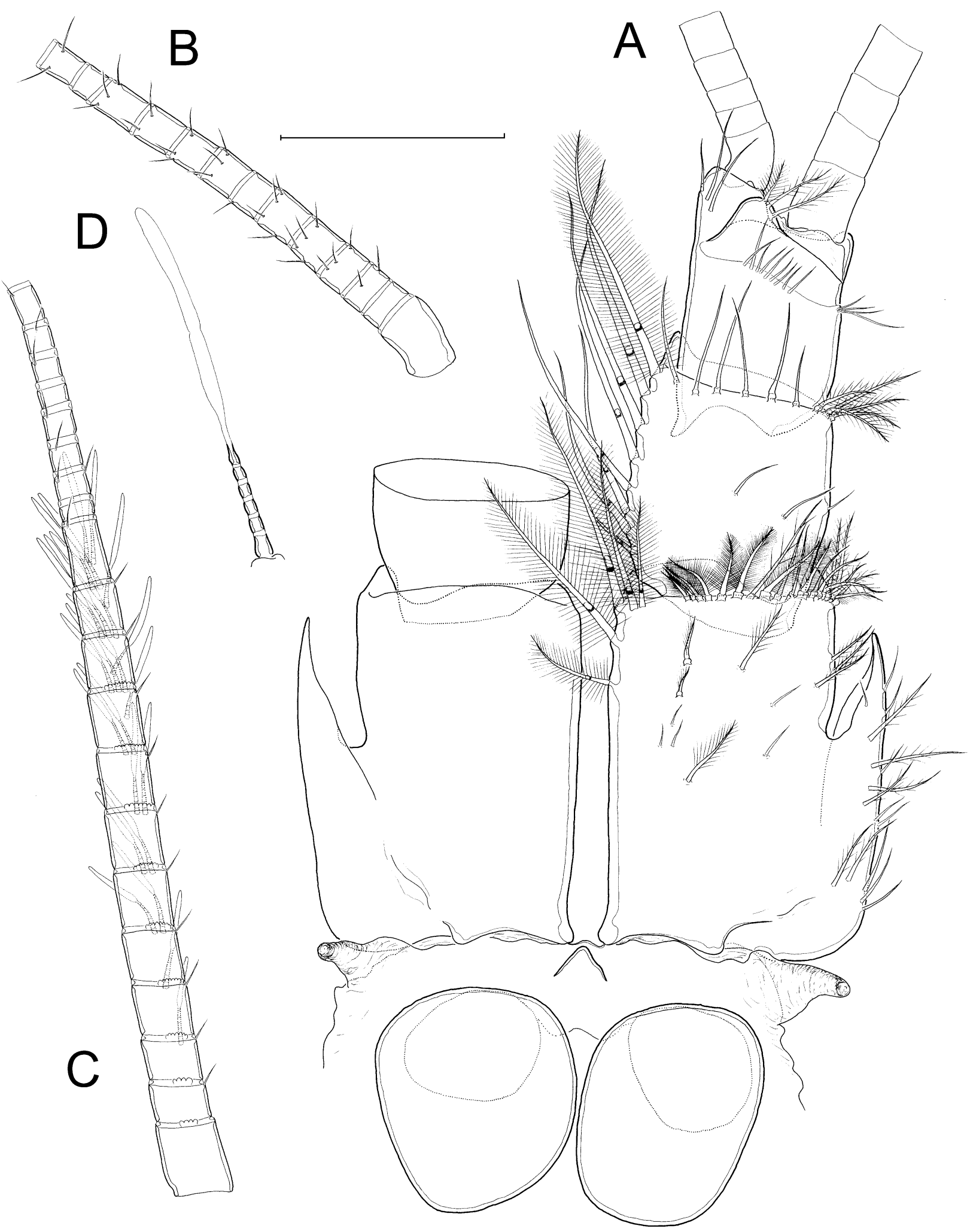

Figure 6. Typhlatya arfeae sp. nov., specimen $17.60 \mathrm{~mm}$, sex unknown. A, proximal part of antennules and anterior part of cephalothorax with carapace removed, dorsal (eyestalks folded back into unnatural position). B, detail of proximal part of inner flagellum of antennule, dorsal. C, same for outer flagellum. D, detail of aesthetasc on outer flagellum. Scale bar: $\mathrm{A}-\mathrm{C}=0.50 \mathrm{~mm} ; \mathrm{D}=0.125 \mathrm{~mm}$. 


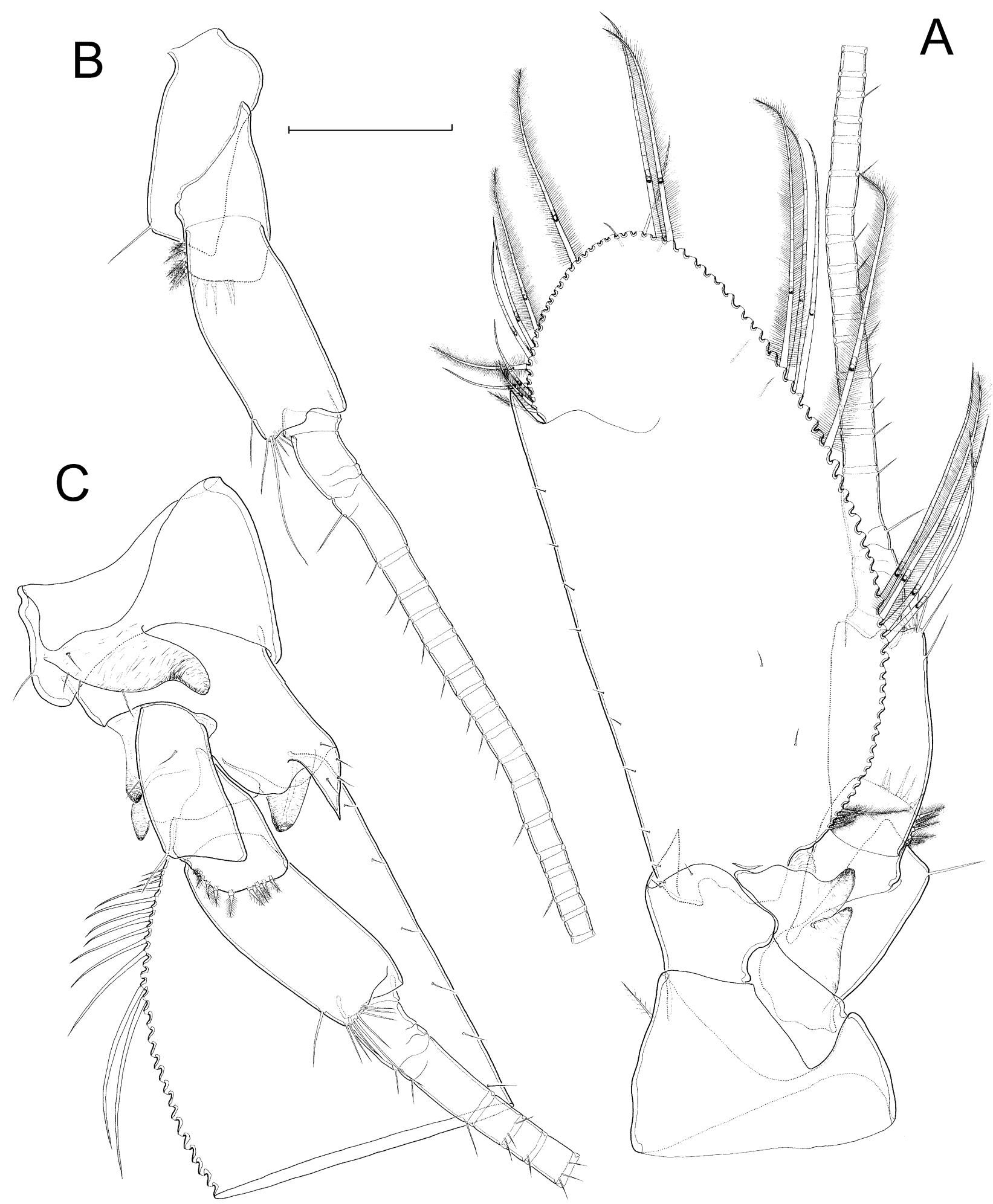

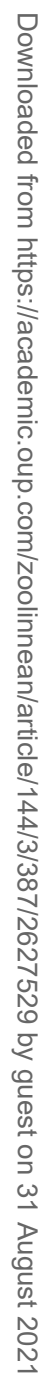

Figure 7. Typhlatya arfeae sp. nov., specimen $17.60 \mathrm{~mm}$, sex unknown. A, right antenna, dorsal. B, detail of three distal segments of peduncle and flagellum of latter, dorsal. C, left antenna, ventral. Scale bar = $0.05 \mathrm{~mm}$. 


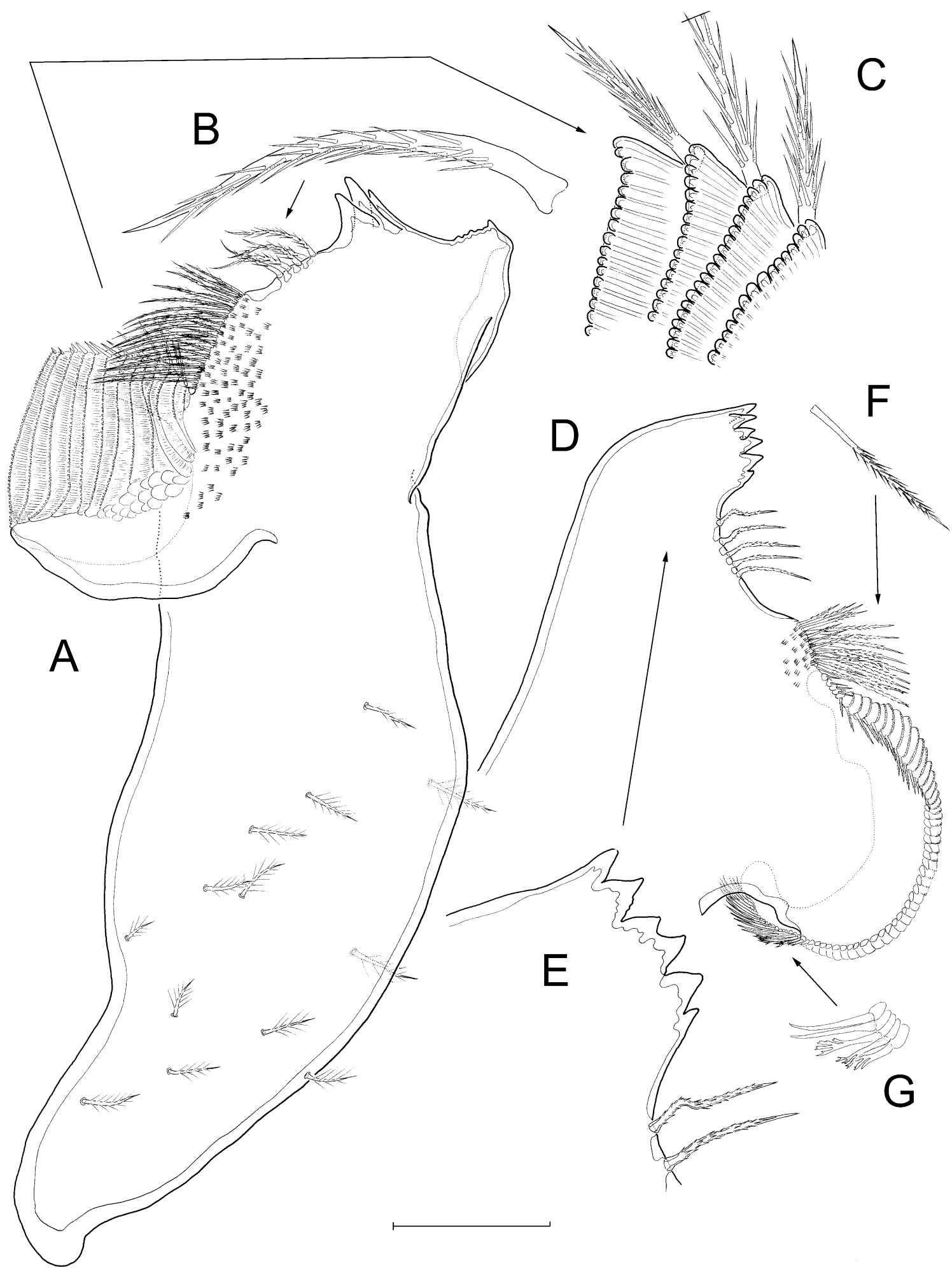

Figure 8. Typhlatya arfeae sp. nov., specimen $17.60 \mathrm{~mm}$, sex unknown. A, left mandible, anterior (= frontal) view. B, detail of element of setal row. C, detail of distal spinules on plates of grinding surface of molar. D, right mandible, posterior. E, detail of incisor and two distal elements of setal row on right mandible. F, detail of spinulose seta on proximal portion of mandibular sinus. G, detail of short dendriform spinules on proximal margin of plates of grinding surface of molar. Scale bar: $\mathrm{A}, \mathrm{D}=0.25 \mathrm{~mm} ; \mathrm{B}, \mathrm{C}=0.05 \mathrm{~mm} ; \mathrm{E}-\mathrm{G}=0.125 \mathrm{~mm}$. 
than on left mandible. Two superimposed rows of setae on mandibular sinus composed of fewer, and stiffer, setae than on left mandible (Fig. 8F). Molar process similar to left counterpart, but proximal margin of grinding plates with short dendriform spinules progressively shorter, absent from plates on molar crown (Fig. 8G); presence of such spinules on left mandible unconfirmed.

Maxillule (Fig. 9A-D) lacking expressed segmentation; tentatively interpreted as comprising coxa with broad, foliaceous endite (= 'proximal lobe' of Fryer, 1977), and two lobes representing the basis with basal endite (= 'distal lobe' of Fryer, 1977), and the endopod. Coxal endite pointed distally, setulose, with armature consisting of two superimposed rows of setae along medial margin; setae disposed in middle portion of anterior row stiff and with truncate tip (Fig. 9C), corresponding to the 'fine funnelling setae of proximal endite' of Fryer (1977). Two roughly parallel clusters of short setae on posterior surface of lobe; those comprising middle cluster with brush-like tips (Fig. 9B; setae probably homologous with the 'lifting spines of the proximal endite' of Fryer, 1977: fig. 78). Basal endite spatulate; distal half of medial margin with two parallel rows of stout conical spines with rounded tubercles (Fig. 9D); remaining armature on margin and on lateral surface of endite as figured. Endopodal lobe finger-like, with four subdistal setae.

Maxilla (Fig. 10A) phyllopodial, biramous, with basic structure corresponding tentatively to coxa with endite, basis with bilobed endite, reduced finger-like endopod and unsegmented exopod (= scaphognathite). Intersegmental articulations not expressed except partially between coxa and basis. Coxal endite (= 'proximal endite' of Fryer, 1977) with marginal comb row of long setae each swollen proximally; proximal and distal setae of comb row plumose, others rigid and apparently smooth; posterior surface of endite with row of about nine rigid setae each bipinnate distally; anterior surface of endite with cluster of heterogeneous setae (some plumose proximally but smooth distally, some fully plumose, some bipinnate distally, and others apparently completely smooth) arranged as in Figure 10B. Basis indistinct, with three plumose setae, one on medial margin, two on posteromedial surface of segment.

Proximal endite lobe (= 'teaseling lobe' of Fryer, 1977) with proximal margin slightly convex, medial margin straight, and distal margin oblique, not reaching distal margin of distal endite lobe. Posterior surface of lobe unarmed, anterior surface densely covered with rigid setae each unipectinate distally (Fig. 10E), arranged in parallel oblique rows (Fig. 10C); medial margin of lobe with sparsely set, smooth setae with rounded tips (Fig. 10F) mixed with typical unipecti- nate setae; row of slender setae with bipinnate tips (Fig. 10D) lying close and parallel to insertion of endite on anterior surface of segment. Distal endite lobe (= 'distal endite' of Fryer, 1977) spatulate, not extending beyond distal margin of scaphognathite, with heterogeneous array of armature elements consisting of plumose setae with smooth distal part, plumose setae with unipectinate distal part, smooth setae with rounded tip, and denticulate spines (as Fig. 10G); several additional plumose setae located distomarginally on anterior surface of lobe.

Scaphognathite (= exopod) inserted on lateral margin of basis, distal lobe truncate, proximal lobe (='caridean lobe') well developed; margins fringed with plumose setae, those on distal margin of distal lobe longer and with several transverse endocuticular interruptions giving a segmented appearance. Endopod (= palp sensu Monod \& Cals, 1970) extending to middle of distal lobe of scaphognathite, smooth except for three minute plumose setae inserted proximally on outer margin.

First maxilliped (Fig. 11A) phyllopodial, biramous, with coxa, basis, exopod and endopod indistinctly separated. Coxa with rounded endite bearing complex armature array comprising two marginal rows of long setae (Fig. $11 \mathrm{~F}$ ), one row of smooth geniculate setae with denticulate tips (Fig. 11G), and one of plumose setae with smooth tips; numerous short plumose setae each with smooth distal part set sparsely on anterior surface of endite, plus three setae with denticulate tips on anterior surface near distomedial margin. Coxal epipodite short, conical, with short smooth seta on tip instead of lamelliform podobranch apparently present in homologous position in T. iliffei (see Hart \& Manning, 1981: fig. 38).

Basis indistinct, bearing row of about six long plumose setae, each with smooth distal part, on anterior surface, and row of about 14 shorter setae on posterior surface. Basal endite elongate, subrectangular, with complex armature comprising plumose setae with smooth distal portion and pointed tips, same type of setae but with rounded tips, short smooth setae with rounded tips (Fig. 11D), and plumose setae with denticulate tips (Fig. 11E); medial margin of endite with row of tightly set, rigid plumose setae displaying transverse lamellar expansions distally (Fig. 11B, C).

Exopod subrectangular, with distomedial corner produced into elongate process ('flagellar lobule' of Hobbs \& Hobbs, 1976) extending about $46 \%$ of total length of segment. Lateral and distal margins of segment fringed with plumose setae; inner margin and margins of flagellar lobule with plumose setae each smooth distally. Anterior surface of segment with sparsely set plumose setae with smooth distal parts and several short smooth setae distributed as figured. 


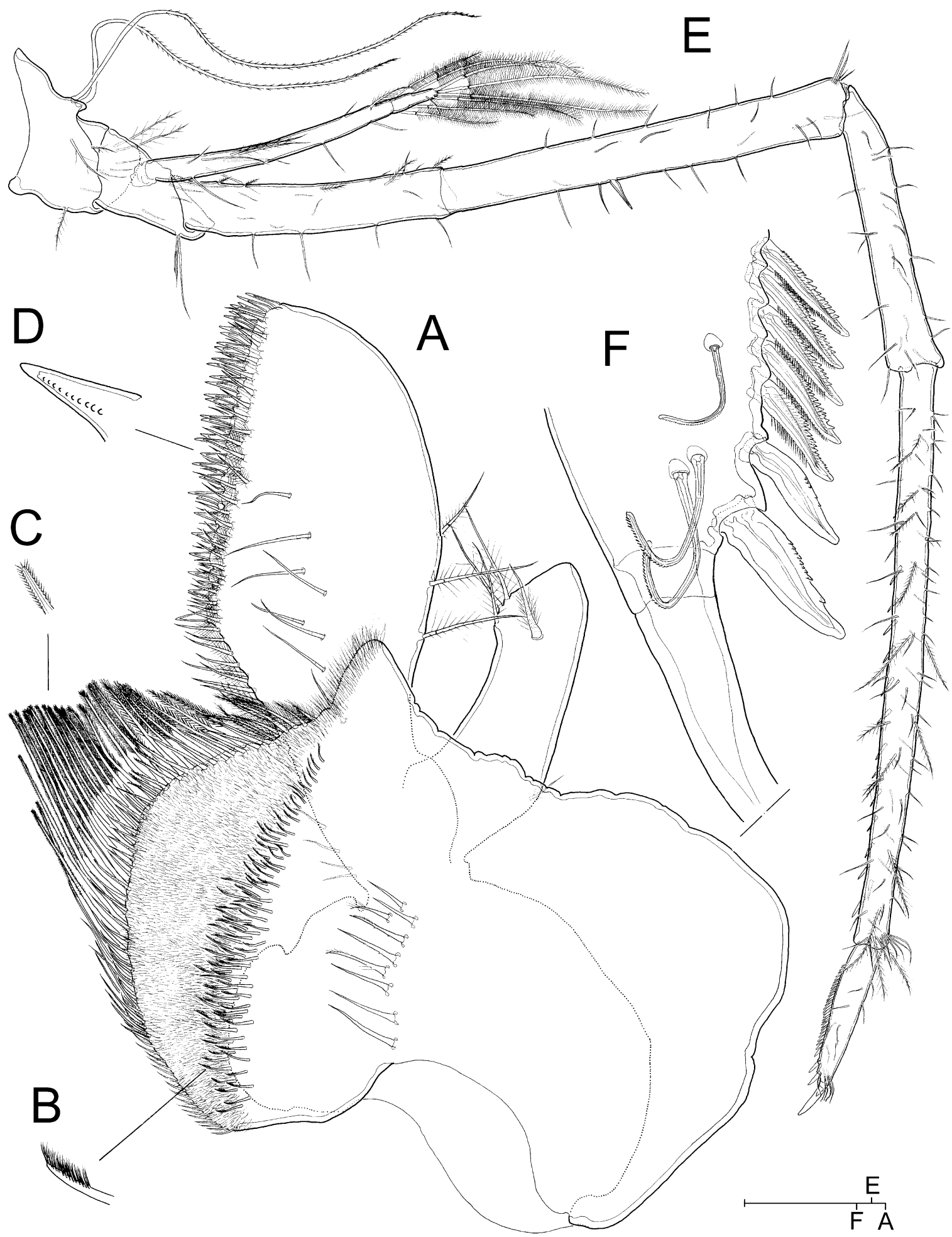

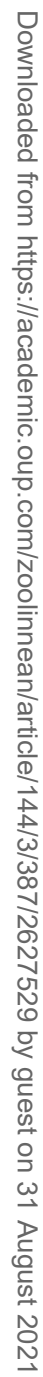

Figure 9. Typhlatya arfeae sp. nov., specimen $17.60 \mathrm{~mm}$, sex unknown. A, left maxillule, posteromedial view. B, detail of seta with brush of pinnules on tip from middle cluster on posterior surface of coxal endite. C, detail of stiff seta with truncate tip on medial margin of coxal endite. D, detail of conical spine with tubercles on basal endite. E, right fifth pereiopod, lateral. F, detail of armature of dactylus of latter, medial. Scale bars: A = $0.25 \mathrm{~mm} ; \mathrm{E}=0.5 \mathrm{~mm} ; \mathrm{F}=0.05 \mathrm{~mm}$; B-D not to scale. 


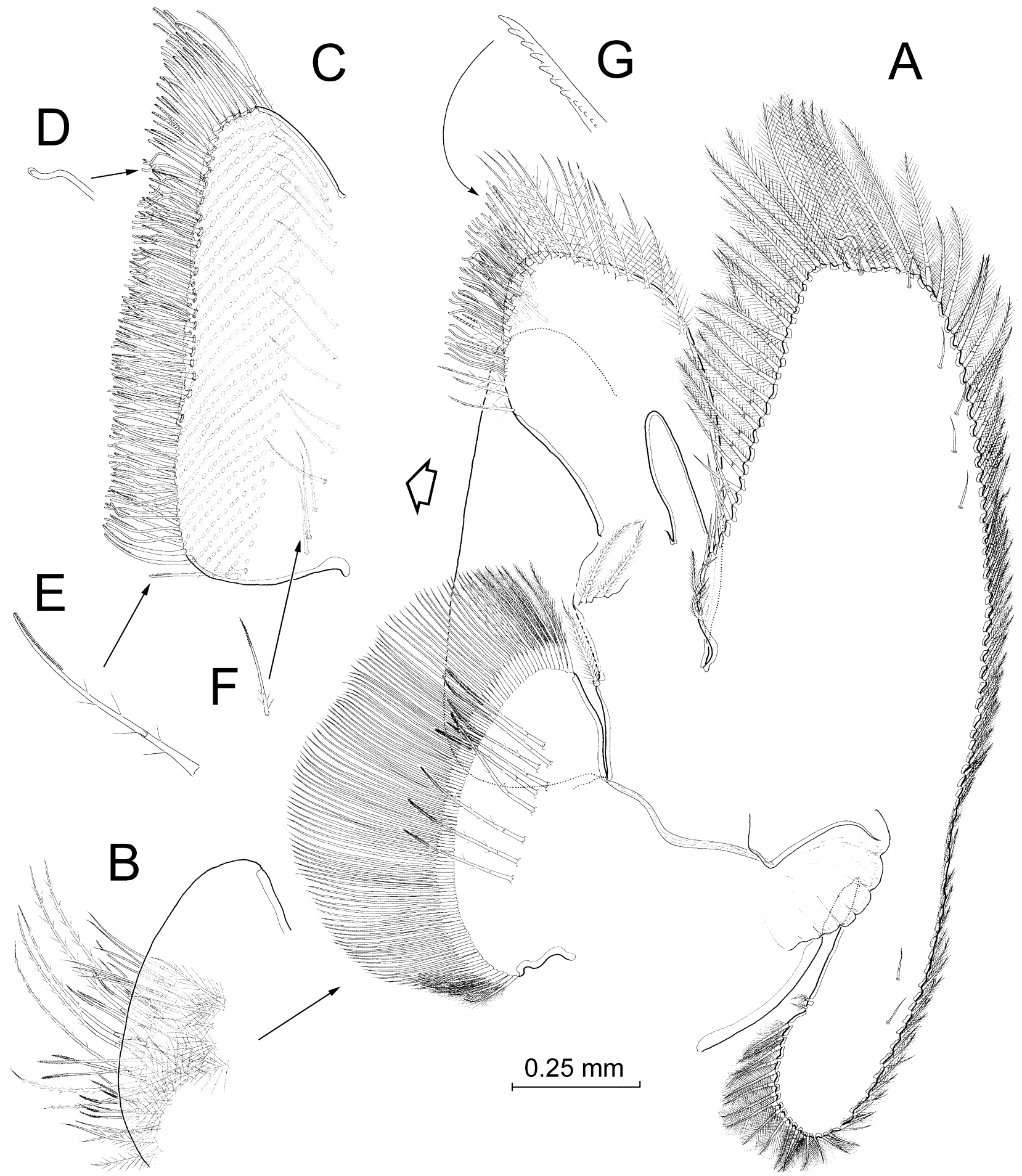

Figure 10. Typhlatya arfeae sp. nov., specimen $17.60 \mathrm{~mm}$, sex unknown, left maxilla. A, general view with proximal lobe of basal endite outlined only, posterior. B, detail of coxal endite showing armature on anterior surface only, posterior. C, detail of proximal lobe of basal endite with most armature elements on anterior surface removed and their origins indicated by circular scars, posterior. D-F, detail of armature elements on proximal lobe of basal endite. G, detail of denticulate spine on distal lobe of basal endite. D-G not to scale. 


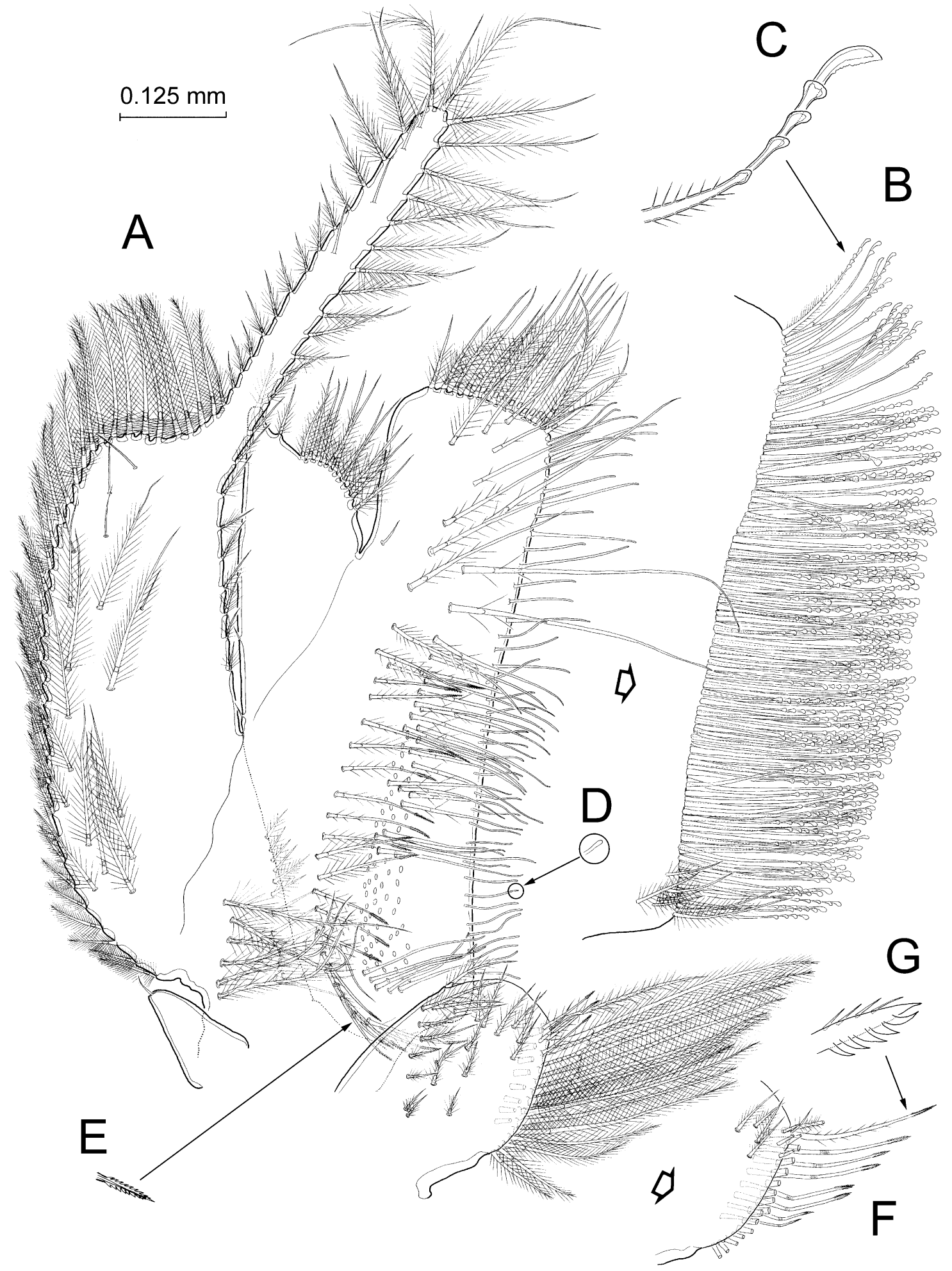

Figure 11. Typhlatya arfeae sp. nov., specimen $17.60 \mathrm{~mm}$, sex unknown, left first maxilliped. A, anterior view with armature on medial margin of basal endite omitted. B, detail of armature. C, detail of rigid plumose seta with transverse lamellar expansions. D, detail of tip of smooth seta with rounded tip from lateral view, surface of basal endite. E, same from plumose seta with denticulate tip. F, detail of armature of coxal endite. G, detail of denticulate tip of geniculate setae of coxal endite. $\mathrm{C}-\mathrm{E}$ and $\mathrm{G}$ not to scale. 
Endopod reaching distal margin of basal endite, roughly triangular; inner (= medial) margin with row of plumose setae with smooth distal part, single similar seta on tip, and two tiny smooth setae on proximal part of outer (= lateral) margin.

Second maxilliped (Fig. 12A) stenopodial with expanded dactylus. Coxa unarmed, with podobranch reaching distal margin of ischium, and no trace of epipod. Basis and ischium almost completely fused, former slightly shorter, with sparsely set plumose setae with smooth distal portion along both margins and on anterior surface of segment, proximalmost seta on medial margin enlarged. Exopod elongate and slender, bowed, with plumose setae with smooth distal part along both margins of proximal part of segment; middle part of segment naked; distal part with plumose setae along both margins, setae with transverse endocuticular interruptions giving a segmented appearance; two short smooth setae on anterior surface of segment as figured.

Ischium with row of heterogeneous setae along medial margin (some plumose, others with denticulate tips as in Fig. 12B). Merus about as long as ischium, but more slender, with row of plumose setae with smooth distal parts along medial margin. Carpus half length of merus, with digitiform process with microtuberculate ornamentation distally, on anteromedial surface; armature of segment reduced to single plumose seta with smooth distal part positioned subdistally on lateral margin. Propodus with expanded distal margin covered with smooth rigid setae, denticulate setae, and long plumose setae with denticulate distal parts and rounded tips (Fig. 12C); latter setae with subdistal pinnules stouter than rest.

Dactylus arising on medial margin of preceding segment and completely incorporated into it except for expression of vestige of intersegmental articulation on posterior surface; dactylus locked into flexed position by rounded process on carpus. Segment falcate, with smooth convex medial (but anatomically lateral) margin and slightly concave lateral (but anatomically medial) margin. Slit connected with duct present proximally on both anterior and posterior sides of segment. Anteromedial surface of segment (Fig. 12D) with smooth rigid setae, long plumose setae with smooth distal part, and single plumose seta distally. Medial margin of segment with row of tightly set, pectinate spines as in Figure 12E, F.

Third maxilliped (Fig. 13A) stenopodial, with small phyllobranchiate arthrobranch (i.e. associated with arthrodial membrane between coxa and body). Coxa with transverse row of plumose setae on inner margin and cluster of setae on distomedial corner; epipod bifurcate, posterior branch slender, not extending beyond coxa distally, with subdistal notch; anterior branch short and roughly conical, unarmed. Basis partially fused to ischiomerus, short, with row of unequal setae along medial margin. Exopod unsegmented, long and slender, bowed, extending beyond distal margin of ischiomerus; armature as described for preceding limb. Relative length of ischiomerus, carpus and propodus as shown in Figure 14. Ischiomerus somewhat bowed, about six times longer than wide, with sparsely set short setae along both margins.

Carpus with 6-7 transverse rows of short bipectinate spines on medial surface of segment (Fig. 13B); row of smooth setae along distal margin. Propodus with heterogeneous array of transverse rows of spines on medial surface of segment, as follows: six rows of short bipinnate spines with expanded hyaline tips (Fig. 13C; cochlear setae of Monod \& Cals, 1970; 'distally spatulate setae' of Hobbs \& Hobbs, 1976) on proximal half of segment; four rows of spines with serrate triangular denticles along one margin only and with spinulose tips (Fig. 13D) located adjacent to preceding rows of spines; and about 12 smooth, conical spines (Fig. 13E) along distal part of segment; latter spines indistinguishable from larger terminal spine, interpretable as dactylus.

First pereiopod (Fig. 13F) chelate, with tip of propodus and dactylus covered with tuft of heterogeneous spines and setae (similar to those on second pereiopod, described in detail below and Fig. 15B-G). Coxa, basis and exopod as in third maxilliped except for uniramous coxal epipodite (nevertheless similar to posterior branch of third maxilliped), presence of 2-4 long pinnate coxal setae ('setobranchs') on small outgrowth near origin of epipodite, and basis completely separated from ischium. Ischium completely separate from and slightly shorter than merus, both segments bearing few short smooth setae on both margins. Carpus with protruding conical outgrowth located about two-thirds distance along lateral margin; several smooth setae on outgrowth and margins of segment as figured. Chela (propodus + dactylus) slender, about 2.7 times longer than wide, with dactylar (= outer) process clearly extending beyond tip of propodal (= inner) process. Relative length of ischium + merus, carpus and propodus as in Figure 14.

Second pereiopod (Fig. 15A) chelate, similar to preceding limb but more elongate due to ischium, merus and carpus proportionally longer (see Fig. 14). Exopod proportionally shorter, reaching distal margin of merus only (exopod reaching almost to conical lateral process on propodus in preceding limb; nevertheless, both exopods about equal in absolute length). Three 'setobranch' setae present on coxa. Chela similar to preceding limb both in size and armature, with terminal tuft of setae on dactylar process composed of heterogeneous array of spines and setae, as follows: 


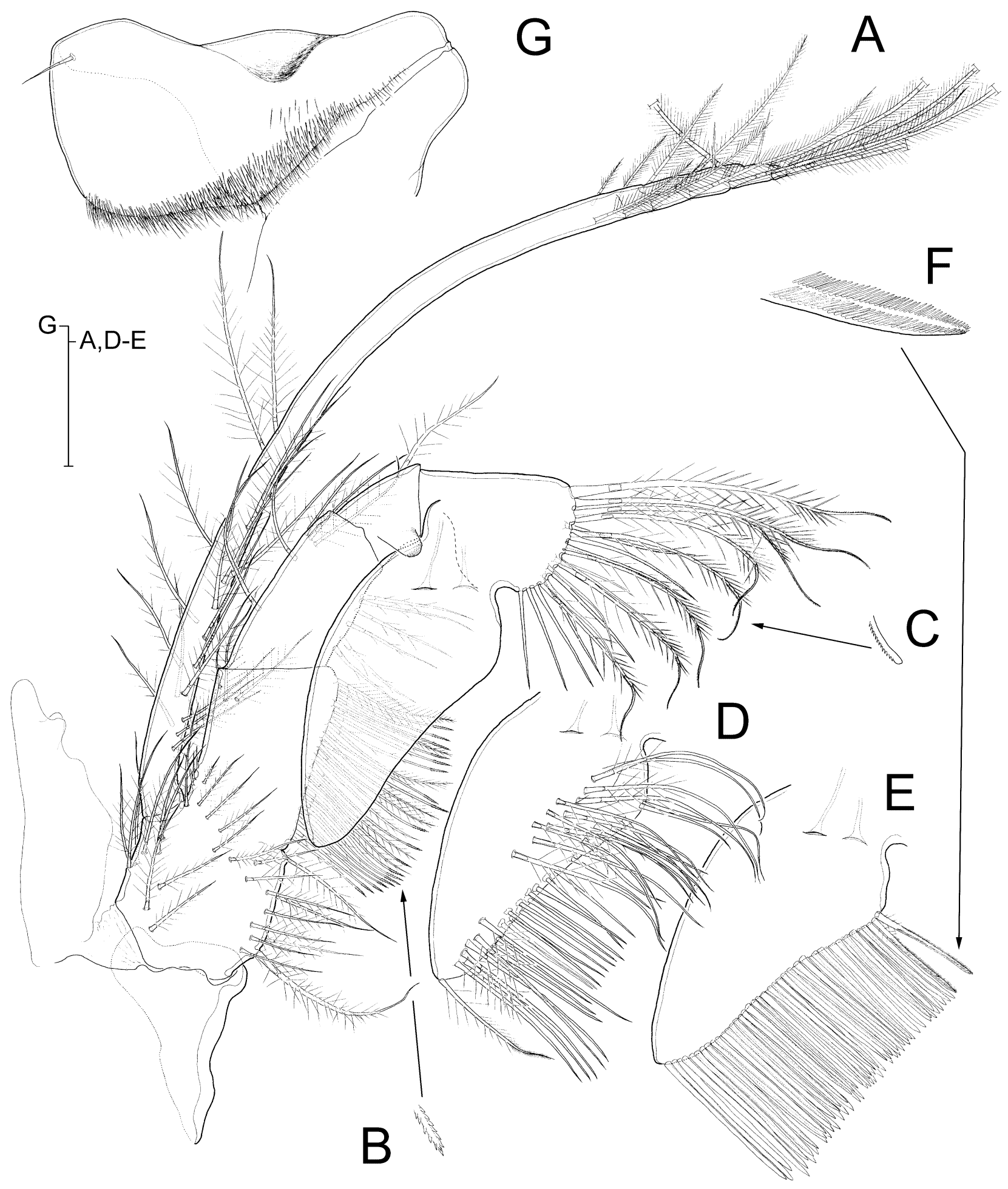

Figure 12. Typhlatya arfeae sp. nov., specimen $17.60 \mathrm{~mm}$, sex unknown, left second maxilliped. A, general view with dactylus outlined only, anterior. B, detail of denticulate tip of seta on medial margin of ischium. C, detail of denticulate tip of plumose seta on distal margin of propodus. D, detail of armature on anteromedial surface of dactylus, armature on medial margin omitted. E, detail of latter armature, with ornamentation of spines omitted except for two most proximal spines. F, detail of one of latter. G, left and proximal part of right paragnath, posterior (= ventral view). Scale bar: $\mathrm{A}, \mathrm{D}, \mathrm{E}=0.125 \mathrm{~mm} ; \mathrm{G}=0.25 \mathrm{~mm} ; \mathrm{B}, \mathrm{C}$ and $\mathrm{F}$ not to scale. 


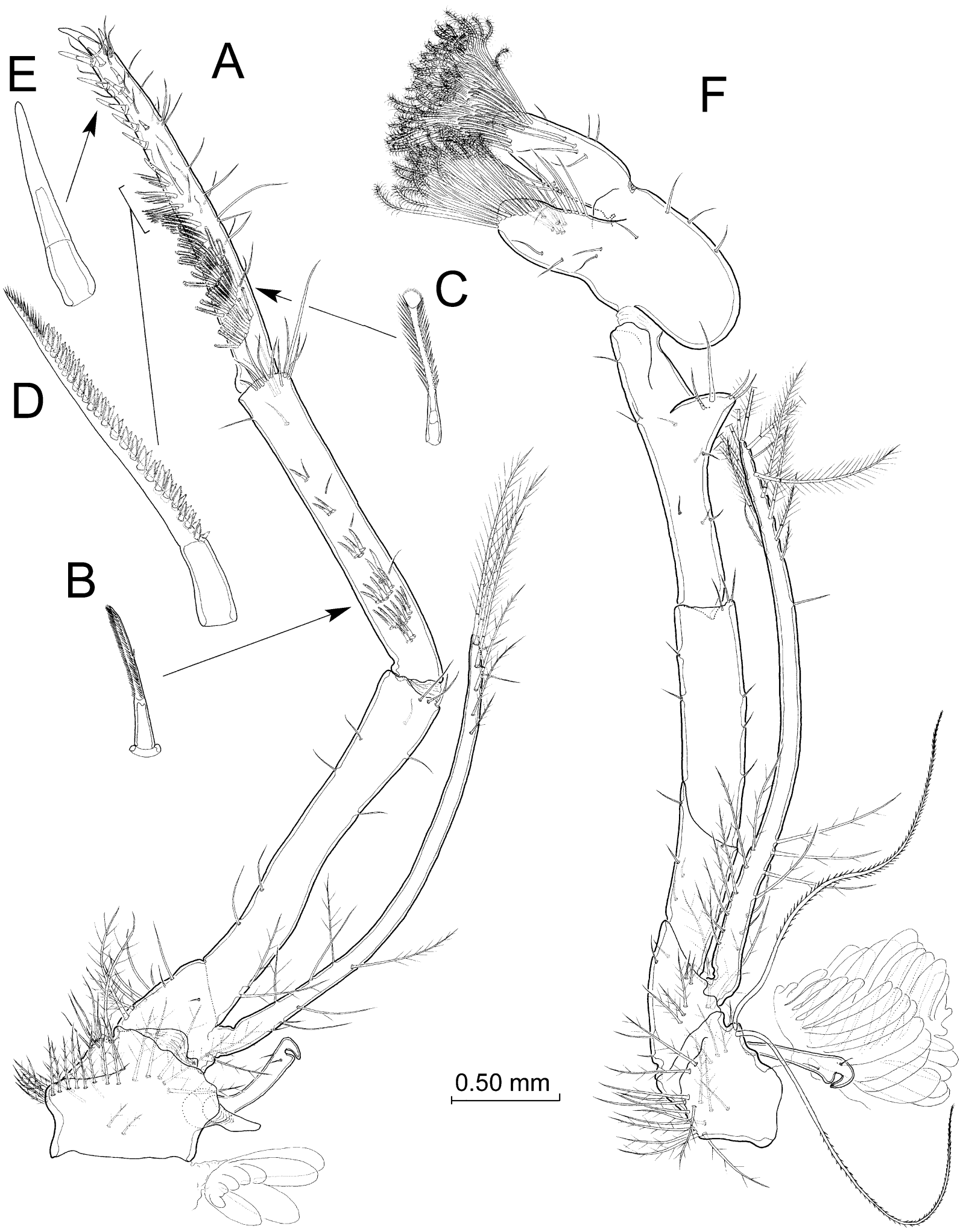

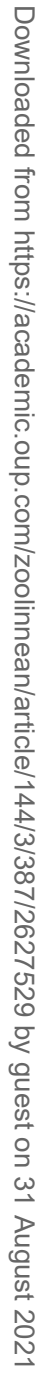

Figure 13. Typhlatya arfeae sp. nov., specimen $17.60 \mathrm{~mm}$, sex unknown. A, general view of right third maxilliped with corresponding arthrobranch, anteromedial. B, detail of bipectinate spine on medial surface of carpus. C-E, detail of several spines of heterogeneous array comprising medial armature of propodus. F, left first pereiopod and fourth thoracomere pleurobranch, anteromedial. B-E not to scale. 


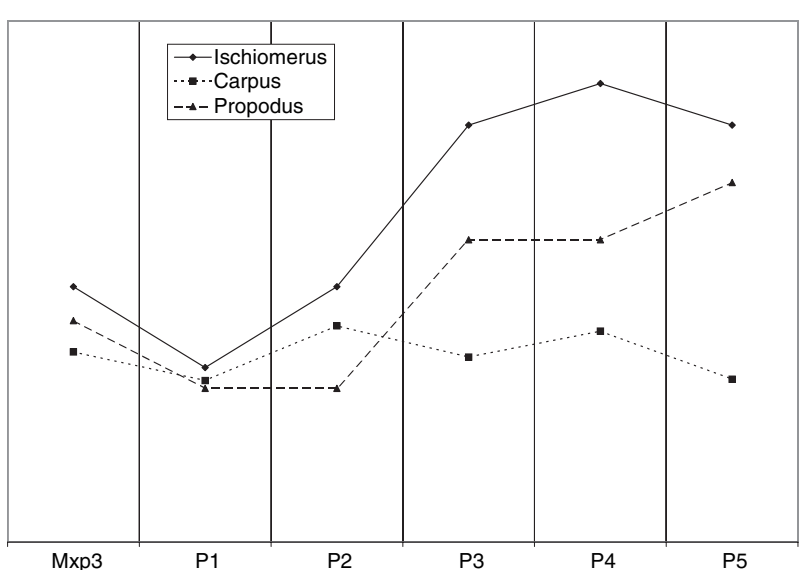

Figure 14. Typhlatya arfeae sp. nov., specimen $17.60 \mathrm{~mm}$, sex unknown. Relative length of ischiomerus, carpus and propodus of third maxilliped (Mxp3) and pereiopods 1-5 (P1-P5).

Four stout sigmoid spines mid-ventrally, each with expanded tip and with transverse lamellar processes along posterior margin (Fig. 15B, C); spines apparently lacking internal canal described by Monod \& Cals (1970: 67, fig. 6) for Typhlatya galapagensis. Sigmoid spines partially hidden by several rows of setae evolving progressively in form from innermost to outermost rows from coarsely serrate (Fig. 15D) to finely serrate scrapers (Fig. 15E), flexible finely unipinnate setae (Fig. 15F), and finally flexible setae with terminal brush (Fig. 15G). Terminal tuft on propodal process similar to that on dactylus but lacking sigmoid spines.

Third pereiopod (Fig. 16A) long and slender, stenopodial, with coxa, basis and exopod as in preceding limb; tip of exopod reaching about two-thirds of merus. Ischium incompletely separated from merus, about 4.7 times longer than wide, with one spine on medial margin. Merus with two spines on medial margin. Carpus lacking spines. Propodus with row of about 15 small spines along medial margin. Relative lengths of ischiomerus, carpus and propodus as in Figure 14. Dactylus slender, with eight short, stout smooth spines on medial margin (Fig. 16B); spines progressively longer towards distal part of dactylus. Unguis smooth, with faint transverse endocuticular interruption proximally.

Fourth pereiopod (Fig. 16C) as for preceding limb except for relatively shorter ischiomerus and carpus (see Fig. 14), and for slight differences in number of armature elements, as follows: one additional medial spine present subdistally on merus, and 7-9 spines along medial margin of dactylus (Fig. 16D).

Fifth pereiopod (Fig. 9E, F) as for two preceding limbs except for relative length of ischiomerus, carpus and propodus (see Fig. 14), absence of coxal epipodite, presence of only two coxal 'setobranch' setae instead of three, only one spine on inner margin of merus, shorter exopod (as long as ischium only), and armature of medial margin of dactylus, consisting of series (grooming comb?) of about 19-28 similar spines, denticulate along one side, pinnate on other, and with additional row of pinnules dorsally; two additional, longer and stouter spines positioned distal to series, with ornamentation reduced to few marginal denticles on one side only (see Fig. 9F).

Pleopods 1-5 biramous. Pleopod 1 somewhat shorter than pleopod 2, others decreasing progressively in length from 2 to 5 . Protopods with evidence of subdivision (into coxal segment?) proximally, partially fused to basis anteromedially (Fig. 17C); protopod of pleopod 5 with row of smooth setae along lateral margin (Fig. 17F), protopods of pleopods 1-4 with setation reduced to two short setae on distolateral margin (Fig. 17A, D). Rami of pleopods unequal, exopod longer than endopod, both with marginal setation consisting of plumose setae with transverse endocuticular interruptions giving a segmented appearance. Endopod of all pleopods except first with slender appendix interna with cluster of denticulate retinacles on oblique tip (Fig. 17E); no trace of appendix masculina in any of the specimens studied. Exopod of first pleopod modified, expanded proximally and with distal portion elongate, but variable from hardly developed to well developed, as in Figure 17B; short setae on segment as figured.

Uropods clearly longer than telson (Fig. 18A), with undivided protopod; exopod slightly longer than endopod. Most plumose setae along distal and medial margins of exopod and on margins of endopod, with transverse endocuticular interruptions giving a segmented appearance. Surface of both rami armed with mixed array of short setae, as in Figure 18A-C. Incomplete, sinuous transverse suture line (= diaeresis) on exopod, not reaching inner margin of segment, with short plumose seta and thorn-like spine inserted submarginally, and with row of smooth setules between insertion of spine and outer margin of segment (Fig. 18B). Endopod inserted dorsal to exopod on protopod.

Telson (Figs 4D, E, 18A) elongate, trapezoid, 2.0-2.3 times longer than wide, with two short smooth spines dorsolaterally on each side. Dorsal surface with four pairs of short smooth setae present along midline, plus several setules as in Figure 4D. Distal margin with six pairs of spines, outer two pairs smooth, rest spinulose. Outermost pair shortest, adjacent pair longer and stronger than rest; four inner pairs decreasing progressively in length towards midline (Fig. 4E). 


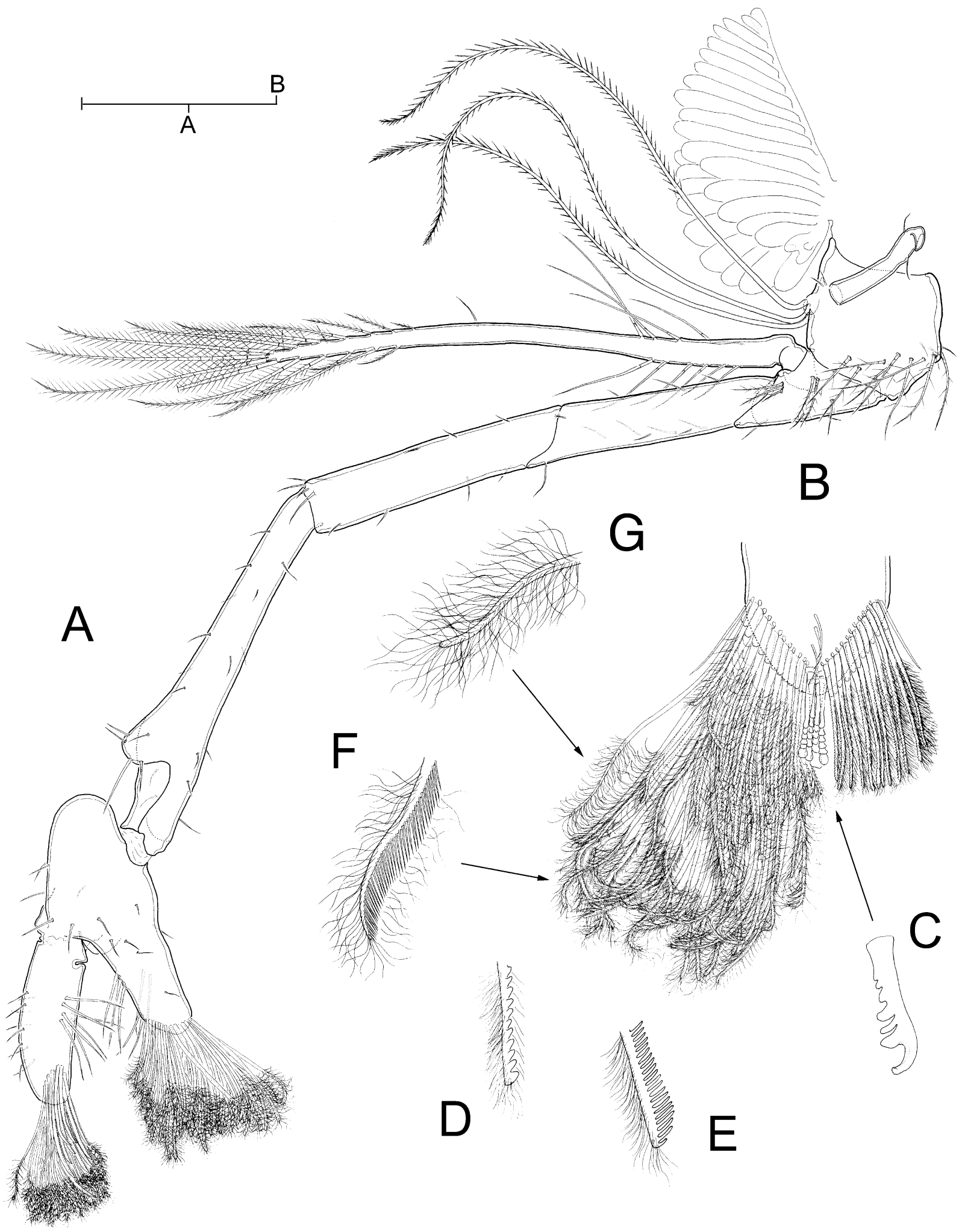

Figure 15. Typhlatya arfeae sp. nov., specimen $17.60 \mathrm{~mm}$, sex unknown, left second pereiopod and corresponding fifth thoracomere pleurobranch. A, general view, lateral. B, ventral view of dactylus, armature on right side partially omitted. C-G, sequence of different morphologies of armature elements of latter, progressing ventral-to-dorsalmost. Scale bar: $\mathrm{A}=0.50 \mathrm{~mm} ; \mathrm{B}=0.25 \mathrm{~mm} ; \mathrm{C}-\mathrm{G}$ not to scale. 


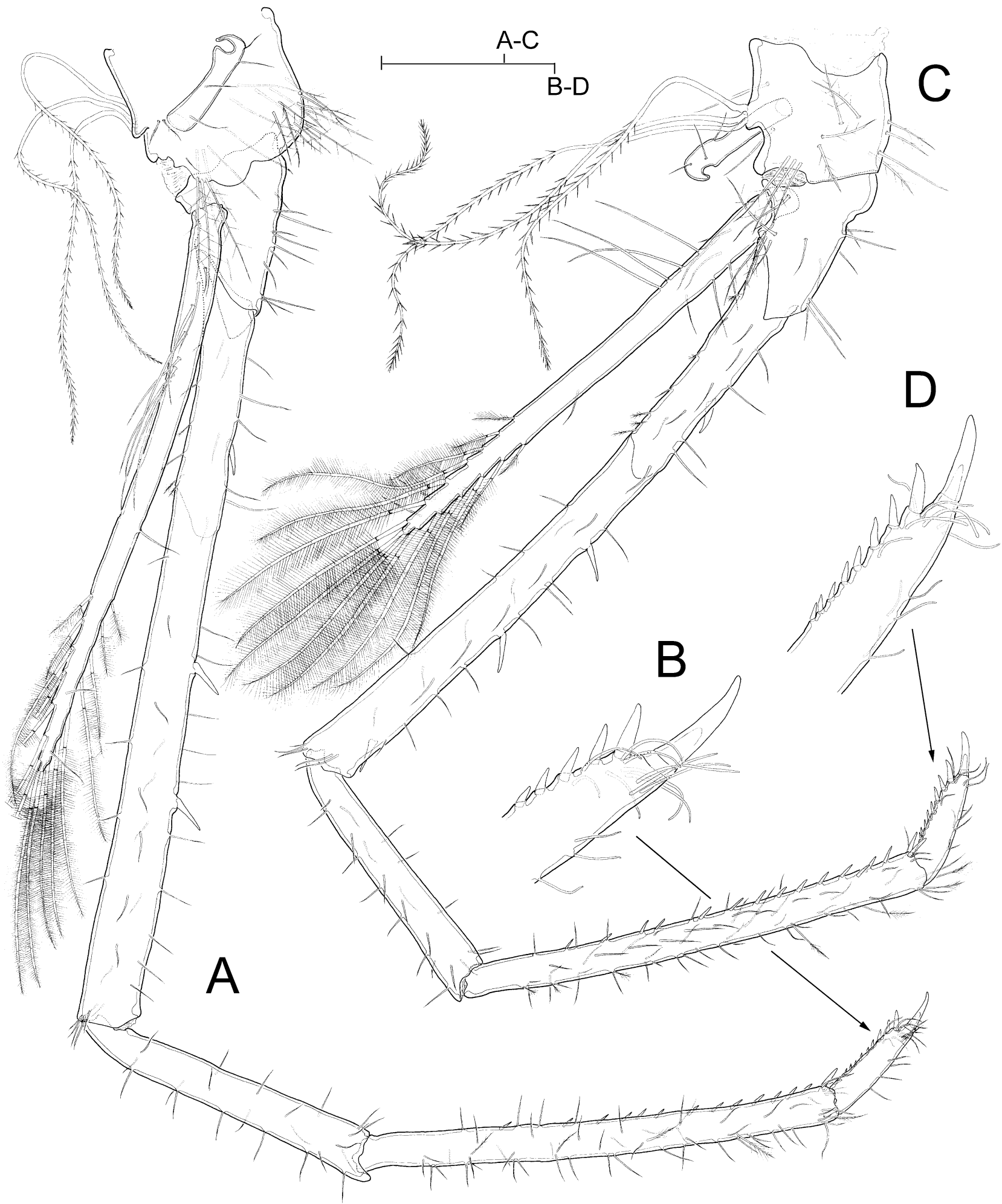

Figure 16. Typhlatya arfeae sp. nov., specimen $17.60 \mathrm{~mm}$, sex unknown. A, left third pereiopod, lateral. B, detail of dactylus + unguis. C, right fourth pereiopod, medial. D, detail of dactylus + unguis. Scale bar: A, C = 0.50 mm; $\mathrm{B}, \mathrm{D}=0.25 \mathrm{~mm}$. 


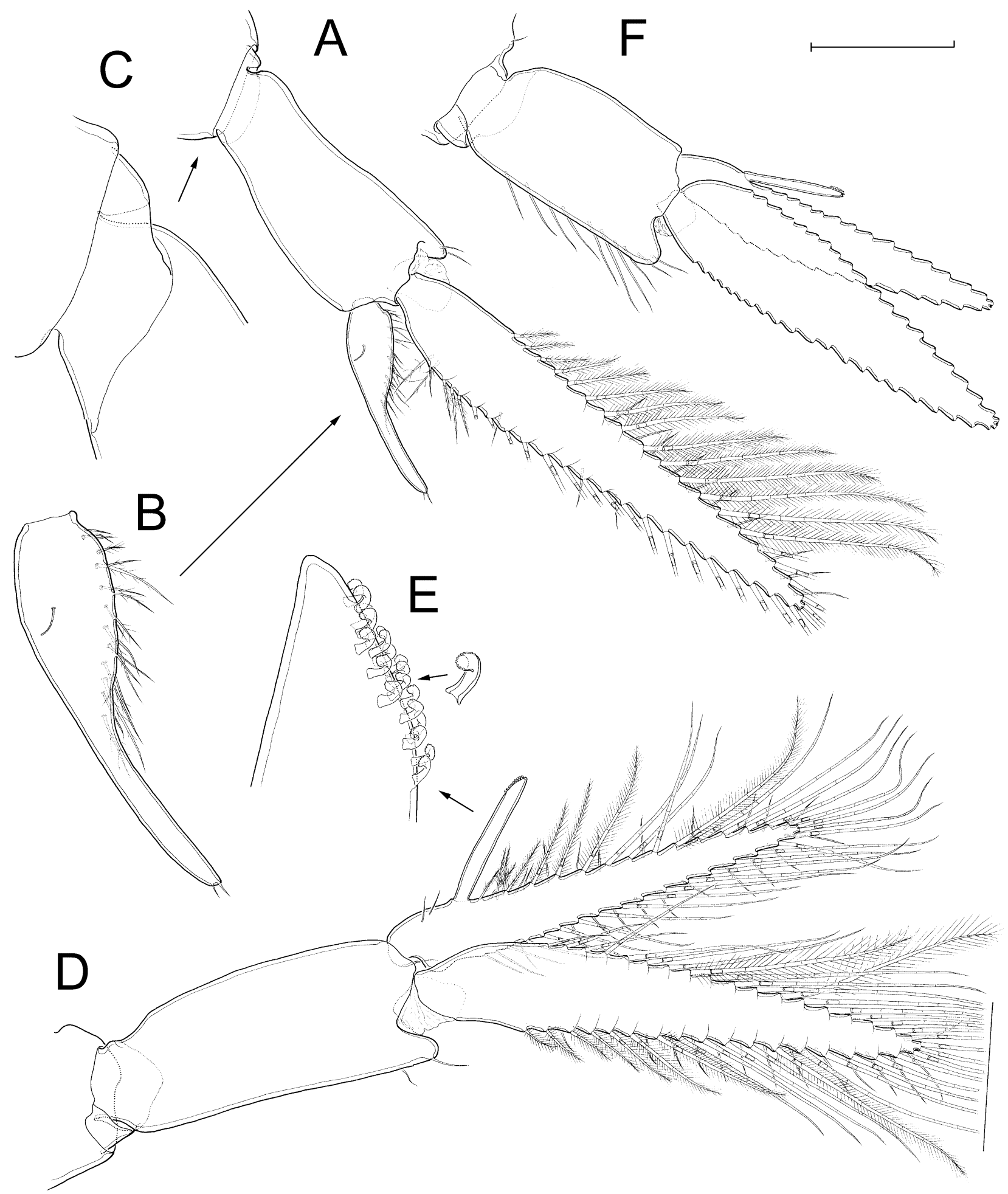

Figure 17. Typhlatya arfeae sp. nov., specimen $17.60 \mathrm{~mm}$, sex unknown. A, left first pleopod, anterior. B, detail of endopod, anterior. C, detail of proximal part of protopod, posterior. D, right second pleopod, anterior. E, detail of tip of appendix interna of latter, and of one of its distal retinacles, posterior. F, right fifth pleopod, anterior. Scale bar: $\mathrm{A}, \mathrm{C}, \mathrm{D}=0.50 \mathrm{~mm}$; $\mathrm{B}=0.25 \mathrm{~mm} ; \mathrm{C}=0.125 \mathrm{~mm} ; \mathrm{E}=0.05 \mathrm{~mm}$ (with detail of retinacle not to scale). 


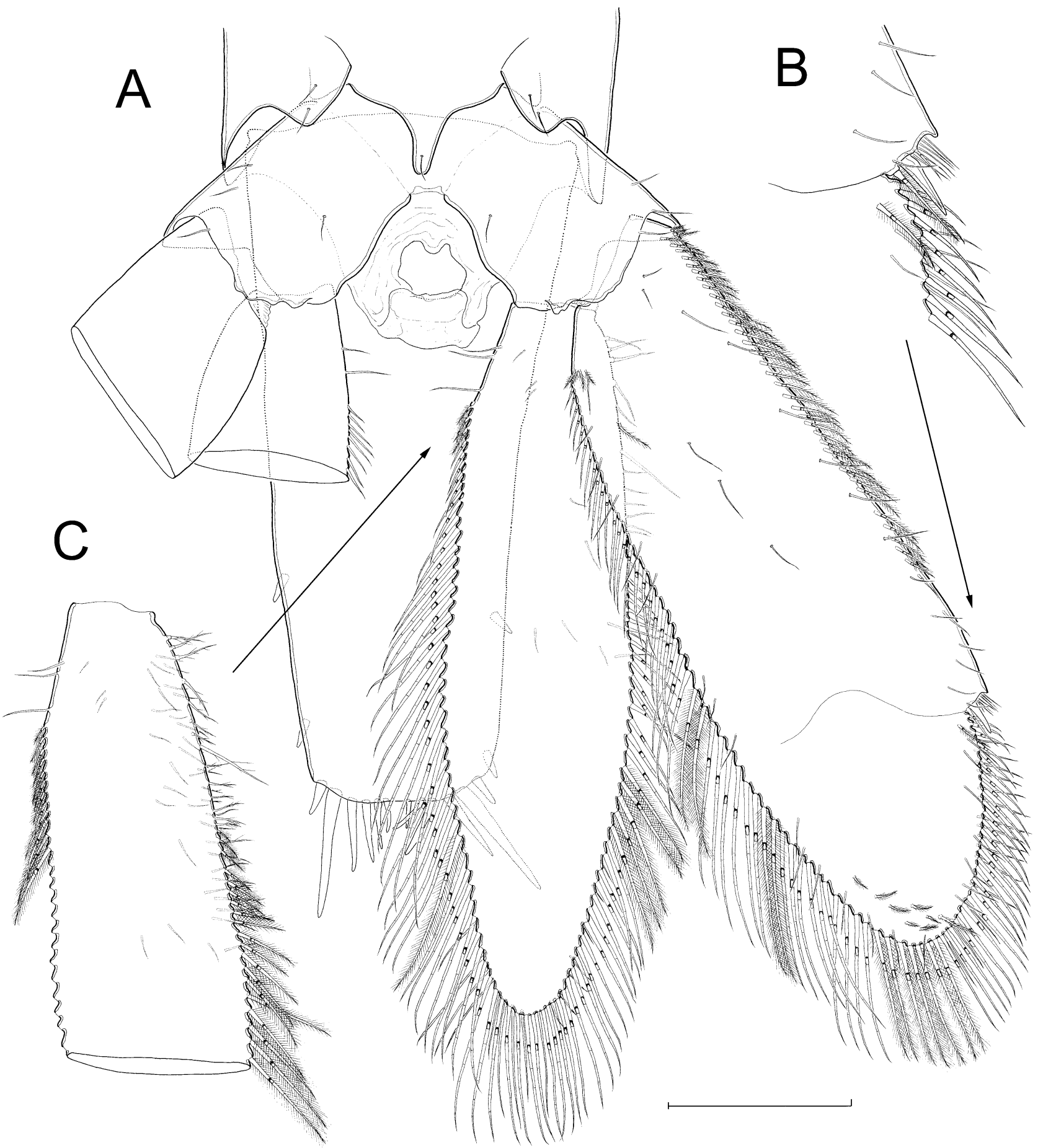

Figure 18. Typhlatya arfeae sp. nov., specimen $17.60 \mathrm{~mm}$, sex unknown. A, sixth pleonite, anus, uropods and telson, ventral view. $\mathrm{B}$, detail of armature of diaeresis of left uropod, ventral. C, detail of armature on proximal portion of left uropodal endopod, ventral. Scale bar: $\mathrm{A}, \mathrm{C}=0.50 \mathrm{~mm} ; \mathrm{B}=0.25 \mathrm{~mm}$. 
Table 1. Species and distribution of the genus Typhlatya Creaser, 1936. In addition to the formally described species, there are records of unidentified species from Curaçao, Bonaire, and Guadalupe islands (Lesser Antilles), and from Isla Juventud (Cuba; see Silva, 1974; Stock, 1993; Sanz \& Platvoet, 1995; Hobbs, 1998)

Species Distribution

Typhlatya iliffei Hart \& Manning, 1981

Typhlatya galapagensis Monod \& Cals, 1970

Typhlatya miravetensis Sanz \& Platvoet, 1995

Typhlatya monae Chace, 1954

Typhlatya rogersi Chace \& Manning, 1972

Typhlatya garciai Chace, 1942

Typhlatya pearsei Creaser, 1936

Typhlatya mitchelli Hobbs \& Hobbs, 1976

Typhlatya campecheae Hobbs \& Hobbs, 1976

Typhlatya consobrina Botosaneanu \& Holthuis, 1970

Typhlatya pretneri (Matjasic, 1956)

Typhlatya garciadebrasi Juarrero \& Ortiz, 2000

Typhlatya taina Estrada \& Gómez, 1987

Typhlatya elenae Juarrero, 1994

Typhlatya jusbaschjani (Birstein, 1948)
Bermuda (Hart \& Manning, 1981)

Galápagos (Sta. Cruz and Isabela Islands: Monod \& Cals, 1970)

Spain (Sanz \& Platvoet, 1995)

Mona Is. (Puerto Rico: Chace, 1954); Puerto Rico (Peck, 1981);

Dominican Rep. (Chace, 1975); Barbuda (Leeward Islands:

Chace \& Hobbs, 1969)

Ascensión (S Atlantic: Chace \& Manning, 1972)

Cuba (Chace, 1942); Providenciales (Caicos Islands: Buden \&

Felder, 1977)

Yucatán peninsula (México: Creaser, 1936)

Yucatán peninsula (México: Hobbs \& Hobbs, 1976)

Yucatán peninsula (México: Hobbs \& Hobbs, 1976)

Cuba (Botosaneanu \& Holthuis, 1970)

Hercegovina (ex-Yugoslavia: Matjasic, 1956)

Cuba (Juarrero \& Ortiz, 2000)

Cuba (Estrada \& Gómez, 1987)

Cuba (Juarrero, 1994)

Georgia (ex-USSR: Birstein, 1948)

\section{Sexual dimorphism}

None of the specimens analysed displayed evidence for appendix masculina on the second pleopods or carried eggs, thus preventing sex determination. Not one displayed the extra-setulation developed on the pleopods and on the margins of the epimeral plates of ovigerous females of some species, such as T. campechae (Hobbs \& Hobbs, 1976: fig. 3a, b; see also Juberthie-Jupeau, 1974). Likewise, none displayed an anteriorly vaulted, pointed extension (thelycum?) of the posterior margin of the sternite of the eighth thoracomere (= thoracomere carrying the fifth pereiopods; see Fig. 4C); this structure seems to develop on (adult?) females in T. galapagensis (see Monod \& Cals, 1970: fig. 58).

\section{Etymology}

The species name is based on the acronym ARFE, Association de Recherches de Font Estramar, and is dedicated to the members of this Association.

\section{DISCUSSION}

The genus Typhlatya currently comprises 15 species (see Table 1), although it is in need of thorough revision. In addition, the validity of genera within the Antecaridina-Stygiocaris-Typhlatya-Typhlopatsa complex has been questioned (d'Udekem d'Acoz, 1999; see also Monod \& Cals, 1970). In fact, inspection of the original descriptions of several Typhlatya species brings their status into question. For example,
T. garciadebrasi, with the third maxilliped lacking spatulate spines on the propodus (an armature displayed by all the species of the genus thus far investigated, and also by Antecaridina Edmondson, 1954 and Stygiocaris Holthuis, 1956; see Monod \& Cals, 1970), and with an extremely elongate sixth pleonite (3.6 times longer than the fifth pleonite, compared to 2.2 times longer, at most, in other species of the genus), should probably be removed from Typhlatya. Similarly, T.jusbaschjani, although a Typhlatya, should be regarded as species inquirenda since its original description contains almost no information of diagnostic value, making the species practically unidentifiable.

In addition, the quality of the original species descriptions is uneven and in many cases inadequate. The characters used to diagnose the species are frequently ambiguous or even wrong. For example, the expression/lack of expression of the ischiomeral intersegmental articulation of pereiopods has been used by Sanz \& Platvoet (1995) as a taxonomically valid character. However, it has been shown above (and by Sanz \& Platvoet, 1995: fig. 3a, d) that this articulation is only partially expressed in both T. arfeae and in T. miravetensis - on one side of the corresponding limbs only - and consequently could easily have been overlooked, or interpreted as completely expressed. The same holds true for the expression of the articulation between the propodus and dactylus in the second maxilliped, considered by Hobbs \& Hobbs (1976) to be of taxonomic value. Sanz \& Platvoet (1995) used 
the presence/absence of plumose setae on the distal part of the pereiopodal exopods as a taxonomic character; but at least in T. galapagensis, one of the three species supposedly lacking such setae according to these authors, they are present (see Monod \& Cals, 1970: 65, fig. 5). Pending reexamination of all representatives of the genus, Table 2 summarizes the valid characters culled from the literature and from personal observations that can be used to distinguish between Typhlatya species.

Careful examination of topotypic material of T. miravetensis has enabled us to elucidate the state of several apparently unusual traits attributed to the species. For example, Sanz \& Platvoet's (1995) description shows a remnant of the inner flagellum on the antenna, whereas in other species there is no trace of a second flagellum on this appendage. The structure described by Sanz \& Platvoet (1995) could be a misinterpretation of the telescoping of the proximal article of the main flagellum into the fifth segment of the antennary peduncle. In addition, they figure an unusually high number of spines on the medial margin of dactylus of pereiopods 3-4 (see Sanz \& Platvoet, 1995: fig. 3d, e), when the typical number of such spines in other species does not exceed nine.
Again, examination of topotypic material has revealed that the species displays the typical number of spines (see Fig. 19A, B). Other inconsistencies in the original description can be explained by the confusion between left and right mandibles (see Sanz \& Platvoet, 1995: fig. 1c, d), and by the swapping of the labels between the figures of the maxilla and first maxilliped (their fig. $2 \mathrm{a}, \mathrm{b}$ ). Finally, the apparent absence of a caridean lobe on the scaphognathite of the maxilla of T. miravetensis could not be confirmed since dissection of the specimens was not permitted.

Typhlatya arfeae sp. nov. is almost identical to T. miravetensis, differing only in details of the armature on the medial margin of the dactylus of the fifth pereiopod, and in the shape and degree of development of the rostrum. Differences in armature of the fifth dactylus have been observed to be constant in all specimens analized. T. miravetensis displays a marginal series of about 36 slender spines ornamented with large, sparsely set denticles along one side, and a second row of tiny pinnules along either the other side and dorsally (Fig. 19C, D); this series of slender spines terminates distally in an additional, stouter spine with ornamentation reduced to one row of short denticles along one side, and another row of tiny denticles

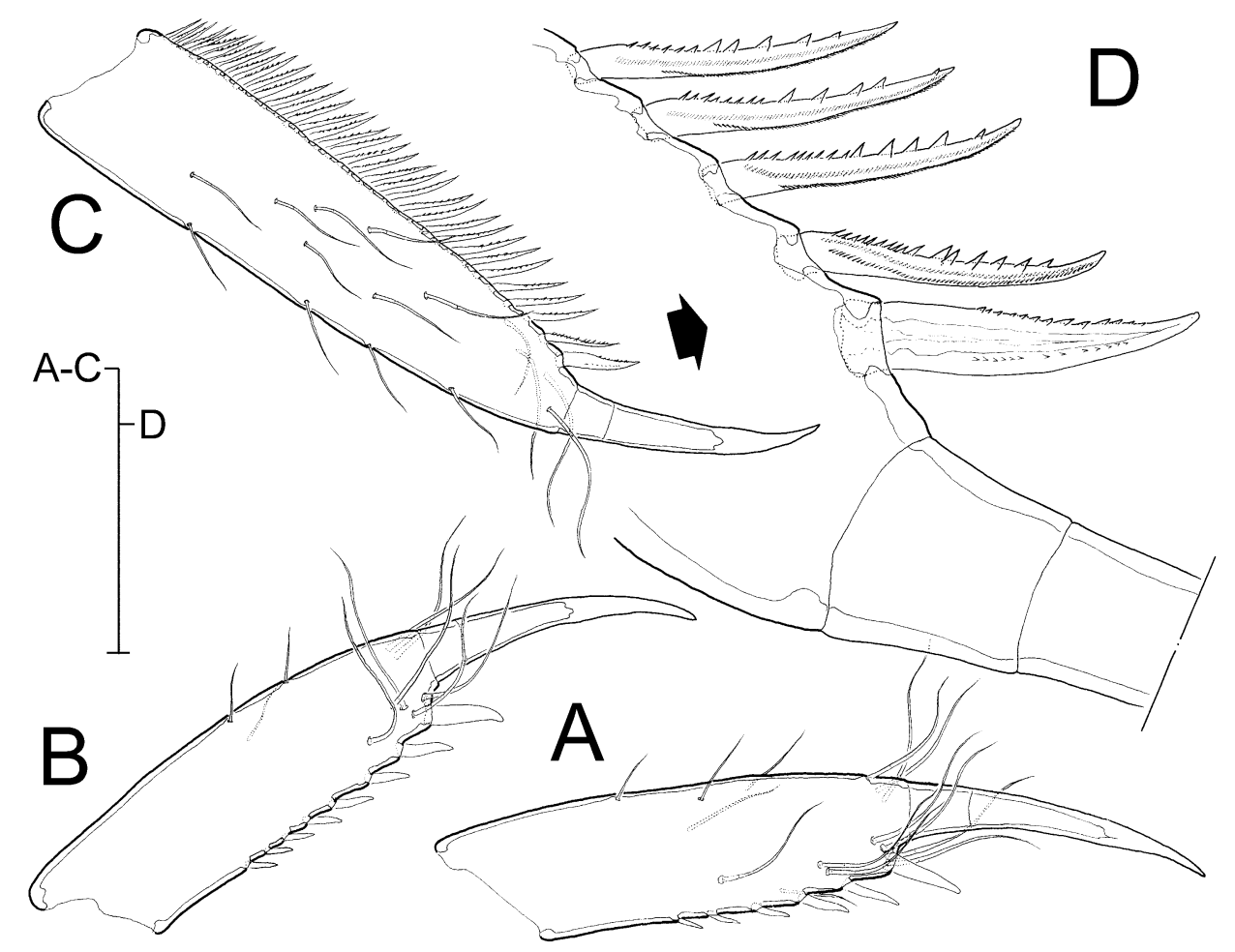

Figure 19. Typhlatya miravetensis Sanz \& Platvoet, 1995, sex unknown. A, detail of dactylus-unguis of third pereiopod. $\mathrm{B}$, same of fourth pereiopod. $\mathrm{C}$, same of fifth pereiopod. D, detail of medial armature of latter. Scale bar: A-C =0.25 mm; $\mathrm{D}=0.05 \mathrm{~mm}$. 


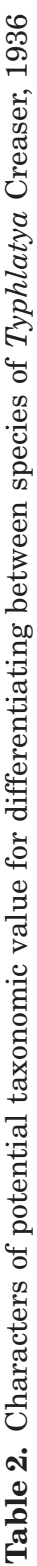

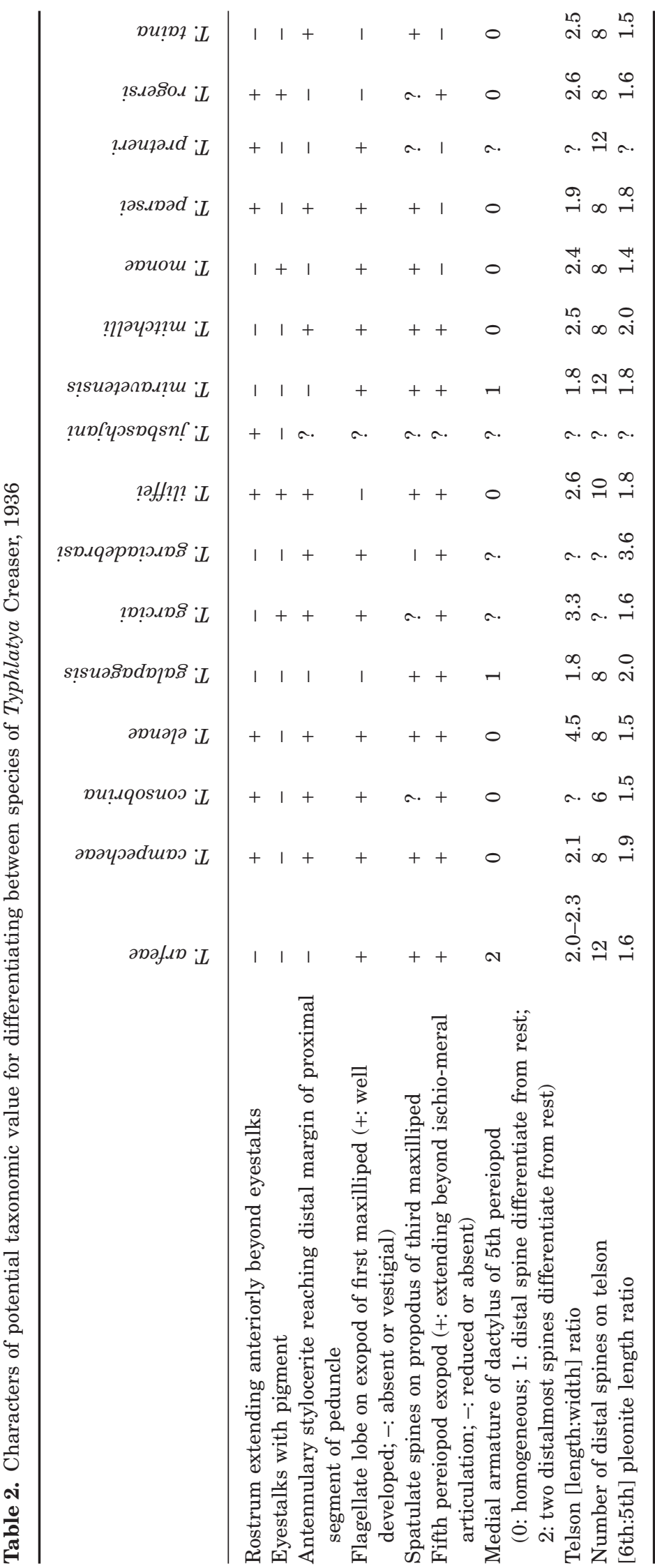

(C) 2005 The Linnean Society of London, Zoological Journal of the Linnean Society, 2005, 144, 387-414 
dorsally. In contrast, the new species displays 19-28 stouter spines along the medial margin of dactylus, and the ornamentation of these spines differs, consisting of a row of tightly set denticles on one side, and a row of long pinnules on the other side and dorsally. In addition, this series of spines ends distally in two longer and stouter spines with ornamentation reduced to few marginal denticles along one side only (see Fig. 9F).

A remarkable trait of $T$. miravetensis, viz. its virtual lack of rostrum (it is reduced to a scarcely developed, rounded vestige in dorsal view, whereas in other species it is variably elongate, triangular), could also be considered as diagnostic for the new species, but one of the three specimens studied by us displayed a faint, weakly developed, pointed rostrum.

Typhlatya arfeae sp. nov. could be sympatric with Troglocaris inermis Fage, 1937, an atyid species reported from the groundwaters of Hérault, about $90 \mathrm{~km}$ to the north of the known range of Typhlatya arfeae. However, Troglocaris can be easily differentiated by the presence of supraorbitary and suborbitary spines on the carapace, the longer rostrum, extending anteriorly beyond the eyestalks, the vestigial exopod on the fourth and fifth pereiopods, and the more elongate sixth pleonite (2.2 times longer than the fifth pleonite, compared to only 1.6 times longer in T. arfeae).

As remarked above, Typhlatya arfeae sp. nov. seems to be very closely related to $T$. miravetensis, recorded from a freshwater cave located $4 \mathrm{~km}$ inland from the coast of Castellón (SE Spain), about $400 \mathrm{~km}$ southwest of the range of T. arfeae and with the Pyrenees in between. As regards the possible origin and age of the new species, we adopt some of Sanz \& Platvoet's (1995) suggestions for the genus: (1) ancient age, earlier than late Cretaceous; (2) thalassoid condition; (3) occupation of and speciation in continental waters due to stranding after marine regressions; and (4) that dispersal episodes could have occurred in ancestors of the current species only prior to the development of troglobiosis. We also agree with Sanz \& Platvoet (1995) in considering that the new species, like T. miravetensis, descended from a (common) ancestor that inhabited the shallow coastal waters in a region corresponding to the current Roussillon and Spanish Levant.

Assuming a sister-group relationship between the two species and since the coastline of Roussillon was drastically affected by the Messinian regression (Aunay et al., 2002), we suggest that their common ancestor could not be older than early Pliocene in age, and that it was already a stygobiont taxon adapted to live in shallow-water marine crevicular habitats. Assuming a tropical-temperate origin for the genus, this ancestor could have vanished from the western Mediterranean after the cooling associated with the onset of northern hemisphere glaciation, about
3.0 Mya, as documented for other Mediterranean marine taxa (Raffi, Stanley \& Marasti, 1986; Sorbini, 1988). Indeed, as the genus is completely stygobiont and does not occur in fluvial environments, and as the Pyrenees represent a watershed boundary, we can eliminate any chance of the derivation of one species population from the other by active dispersal, once established in continental waters.

\section{ACKNOWLEDGEMENTS}

This is a contribution to Spanish MCYT project REN2001-0580/GLO (Anquifauna) and EC Fifth Framework Programme project EVK2-CT-200100121 (Pascalis). We gratefully thank all members of Association de Recherches de Font Estramar (ARFE), and especially Cyrille Brandt, Marc Cottin and Christian Deit, for their support and cooperation during our work in Font Estramar, and Guillaume Tixier for accompanying us to Grotte des Fées de Leucate. We are indebted to Francesc Mezquita and Sebastià Sanz (Universitat de València) for the loan of material of Typhlatya miravetensis. The first author acknowledges the support of the Departement des Milieux et Peuplements Marins, USM 403, Muséum national d'Histoire naturelle (Paris) during the completion of this study.

\section{REFERENCES}

Aunay B, Le Strat P, Aguilar J-P, Camus H, Clauzon G, Dörfliger N. 2002. Introduction à la géologie du karst des Corbières. Orléans: Bureau de Recherches Géologiques et Minières. Rapport BRGM/RP-51595-FR.

Bertrand JY. 1973. Sur le peuplement des eaux souterraines des karsts du Languedoc et des Corbières. Recherches sur les eaux souterraines. Annales de Spéléologie 28: 675-684.

Bertrand JY. 1974. Recherche sur l'écologie de Faucheria faucheri (crustacé Cirolanide). Unpublished Thèse de $3^{\mathrm{e}}$ Cycle, Université Paris VI.

Birstein YA. 1948. The occurence of the cave shrimp Troglocaris in underground water of Macesta and related problems. Bulletin de la Societé des Naturalistes de Moscou 53 (3): 3-10. [in Russian].

Botosaneanu L, Holthuis LB. 1970. Subterranean shrimps from Cuba (Crustacea: Decapoda: Natantia). Travaux de l'Institut de Spéléologie 'Emile Racovitza' 9: 121-133.

Brandt C. 1997. Font Estramar: 11 ans de recherches en plongée dans un grand réseau noyé en bordure de la Méditerranée. In: Jeannin P-Y, ed. Proceedings of the 12th international congress of speleology. Symposium 4: exploration and speleology. La Chaux-de-Fonds, Switzerland, 71-74.

Buden DW, Felder DL. 1977. Cave shrimps in the Caicos Islands. Proceedings of the Biological Society of Washington 90: $108-115$.

Chace FA Jr. 1942. A new cave shrimp from Cuba. Proceedings of the New England Zoological Club 19: 99-102. 
Chace FA Jr. 1954. Two new subterranean shrimps (Decapoda: Caridea) from Florida and the West Indies, with a revised key to the American species. Journal of the Washington Academy of Sciences 44: 318-324.

Chace FA Jr. 1975. Cave shrimps (Decapoda: Caridea) from the Dominican Republic. Proceedings of the Biological Society of Washington 88: 29-44.

Chace FA Jr, Hobbs HH. 1969. The freshwater and terrestrial decapod crustaceans of the West Indies with special reference to Dominica. United States National Museum Bulletin 292: 1-258.

Chace FA Jr, Manning RB. 1972. Two new caridean shrimps, one representing a new family, from marine pools on Ascension Island (Crustacea: Decapoda: Natantia). Smithsonian Contributions to Zoology 131: 1-18.

Creaser EP. 1936. Crustaceans from Yucatan. Carnegie Institution of Washington Publications 47: 117-132.

D'Udekem d'Acoz C. 1999. Inventaire et distribution des crustacés décapodes de l'Atlantique nord-oriental, de la Méditerranée et des eaux continentales adjacentes au nord de $25^{\circ}$ N. Patrimoines Naturels (MNHN/SPN) 40: 1-383.

Encinas JA. 1983. Aportacions cronològiques als gravats rupestres de Mallorca. La cova de Son Sant Martí. Speleon 26/27: 181-193.

Estrada A, Gómez O. 1987. Una nueva especie del género Typhlatya (Decapoda: Atyidae) de Cuba. Poeyana 355: 1-12.

Fryer G. 1977. Studies on the functional morphology and ecology of the atyid prawns of Dominica. Philosophical Transactions of the Royal Society of London B 277: 57-129.

Hart CW Jr, Manning RB. 1981. The cavernicolous caridean shrimps of Bermuda (Alpheidae, Hippolytidae, and Atyidae). Journal of Crustacean Biology 1: 441-456.

Hobbs HH III. 1998. Decapoda (Caridea, Astacidea, Anomura). In: Juberthie C, Decu V, eds. Encyclopaedia Biospeologica, Tome II. Moulis and Bucarest: Société de Biospéologie (CNRS and Academie Roumaine) 891-911.

Hobbs HH III, Hobbs HH. 1976. On the troglobitic shrimps of the Yucatan Peninsula, Mexico (Decapoda: Atyidae and Palaemonidae). Smithsonian Contributions to Zoology 240: $1-23$.

Holthuis LB. 1993. The recent genera of the Caridean and Stenopodidean shrimps (Crustacea, Decapoda): with an appendix on the order Amphionidacea. Leiden: Nationaal Natuurhistorisch Museum.

Jaume D, Wagner HP. 1998. New cave-dwelling amphipods (Lysianassidae, Hadziidae) from the Dominican Republic (Hispaniola). Contributions to Zoology 68: 37-66.

Juarrero A. 1994. Nueva especie de camarón cavernícola (Decapoda: Atyidae: Typhlatya) de Cuba. Avicennia 1: 57-66.

Juarrero A, Ortiz M. 2000. El género Typhlatya (Crustacea: Decapoda: Atyidae) en Cuba, con la descripción de una nueva especie. Avicennia 12/13: 45-54.

Juberthie-Jupeau L. 1974. Les caractères liés à l'incubation chez Troglocaris anophthalmus et T. inermis crustacés décapodes hypogés. Annales de Spéléologie 29: 389-401.

Kiener A, Petit G. 1968. Contribution à l'étude écologique et biologique de la résurgence de Font Estramar et de quelques sources vauclusiennes de la region de Salses-La Nouvelle. Vie et Milieu 19: 241-285.

Ladouche B, Doerfliger N, Izac JL, Cubizolles J, Le Strat P, Du Couëdic C, Aunay B, Thomson P. 2004. Synthèse de la caractérisation des systèmes karstiques des Corbières orientales - Rapport final de la phase I du projet 'évaluation des ressources en eau des Corbières' 2. Caractérisation géologique et hydrogéologique $d u$ système karstique $d u$ synclinal du bas Agly. Orléans: Bureau de Recherches Géologiques et Minières. Rapport BRGM/RP-52919-FR.

Ladouche B, Le Bec C, Aquilina L, Bakalowicz M, Souchu P, Doerfliger N, Anus S. 2000. Recherche de l'origine de la contamination bactériologique de l'étang de SalsesLeucate. Orléans: Bureau de Recherches Géologiques et Minières. Rapport BRGM/RP-50003-FR.

Matjasic J. 1956. Ein neuer Höhlendecapode aus Jugoslawien. Zoologischer Anzeiger 157: 65-68.

Monod T, Cals P. 1970. Sur une espèce nouvelle de crevette cavernicole: Typhlatya galapagensis (Decapoda Natantia; Atyidae). Mission Zoologique Belge aux Îles Galapagos et en Ecuador 2: 57-103.

Peck SB. 1981. Zoogeography of invertebrate cave faunas in southwestern Puerto Rico. National Speleological Society Bulletin 43: 70-79.

Raffi S, Stanley SM, Marasti R. 1986. Biogeographic patterns and Plio-Pleistocene extinction of Bivalvia in the Mediterranean and southern North Sea. Paleobiology 11: 386-388.

Salvayre H. 1978. Spéléologie et hydrogéologie des massifs calcaires des Pyrénées-Orientales. Conflent (special number): $1-249$

Salvayre H. 2002. Le karst des Corbières d'Opoul: Données récentes sur un karst méditerranéen actif. Spelunca 85: 4349.

Sanz S, Platvoet D. 1995. New perspectives of the evolution of the genus Typhlatya (Crustacea, Decapoda): First record of a cavernicolous atyid in the Iberian Peninsula, Typhlatya miravetensis n. sp. Contributions to Zoology 65: 215-296.

Silva G. 1974. Sinopsis de la espeleofauna cubana. Serie Espeleológica y Carsológica 43: 1-45.

Sket B. 1996. The ecology of anchialine caves. Trends in Ecology and Evolution 11: 221-225.

Sorbini L. 1988. Biogeography and climatology of Pliocene and Messinian fossil fish of eastern-central Italy. Bollettino del Museo Civico di Storia Naturale di Verona 14: 1-85.

Stock JH. 1993. Some remarkable distribution patterns in stygobiont Amphipoda. Journal of Natural History 27: 807819.

Stock JH, Illife TM, Williams D. 1986. The concept 'anchialine' reconsidered. Stygologia 2: 90-92.

Wagner HP. 1994. A monographic review of the Thermosbaenacea (Crustacea: Peracarida). A study on their morphology, taxonomy, phylogeny and biogeography. Zoologische Verhandelingen 291: 1-338. 